\title{
Asymmetric Macroeconomic Shocks and Asset Price Behaviors in Selected African Countries
}

\author{
Saliu Mojeed Olanrewaju (Corresponding author) \\ Department of Economics, Faculty of the Social Sciences \\ Ekiti State University, Ado-Ekiti, Nigeria \\ E-mail: mojees4real2@yahoo.com \\ Ogunleye Edward Oladipo \\ Department of Economics, Faculty of the Social Sciences \\ Ekiti State University, Ado-Ekiti, Nigeria \\ E-mail: edladipur@yahoo.com
}

Received: January 24, $2021 \quad$ Accepted: March 26, $2021 \quad$ Published: April 1, 2021

doi:10.5296/ber.v11i2.18481ＵRL: https://doi.org/10.5296/ber.v11i2.18481

\begin{abstract}
This study examines the relationship between Asset prices (Stock and Real estate prices) and Macroeconomic variables in four selected African countries. The study employs the Westerlund Error Correction Based Panel Cointegration test and Eight-variable Structural Vector Autoregressive model to examine the relationship between asset prices and macroeconomic variables. Findings from the study confirm that no long-run relationship exists between both Asset prices and macroeconomic variables. The study equally reveals that portfolio diversification benefits of both stock and real estate markets are more pronounced in the period of a boom than the recession period in Africa. The results also show that GDP growth rate shock exerts a significant impact on both asset prices during expansion and recession periods. The study reveals that foreign interest rates and World oil price shocks are better predictors of both stock and real estate prices during the crisis period than in the expansion period.
\end{abstract}

Keywords: Stock price, Real estate price, Macroeconomic shocks, Structural Vector Autoregressive model, Asymmetry, Error Correction Based Panel Cointegration test 


\section{Introduction}

The stock and property markets which are the two major compositions of the asset market, are vital factors in the transmission mechanisms by which economic activity and the overall macroeconomic level of a country is influenced. The development of asset prices which is embedded in these two major markets is often referred to as one of the indicators of financial equilibrium of which its disruption can lead to a financial crisis in the economy as a whole (Peter and Frank, 2006). Stock and real estate prices are significant catalysts in causing changes in the economic activities, distributing resources to all the important sectors, and strengthening the power base of the financial sectors. According to Carter and Barrett (2006), asset prices act very important roles in the economic policy and financial stability models. Some of these roles comprise of serving as platforms for providing vital information as regard to the market expectation and consumer's risk behaviors, serving as indices of productivity and acting as shocks that influence the economy.

Asset price movements are to a large extent reflected in the real economy through their impacts on consumer and business confidence. A rise in stock prices may signal good economic prospects, which will increase the incentives of the investors to spend and thus influencing consumer confidence and corporate investment. Likewise, the real estate price fluctuations can have real effects on the economy. According to Malpezzi (1999), the wealth effect of real estate prices may contribute to the impact of real estate prices on economic growth by some transmission mechanism through which real estate prices directly affect economic production. For instance, an increase in house prices may imply excess demand which in turn may lead to more construction and more residential investment. The movements in both residential and commercial investment may directly affect economic production.

Given the aforementioned roles of asset prices in any country, it therefore, becomes necessary to be acquainted with the factors that influence asset price movements and the reactions of an asset price to such factors. Having a sufficient understanding of the determining factors of the asset price movement among the macroeconomic fundamentals, will enhance an effective policy decision making and effective risk management mechanisms.

Because of an increase in the global financial market integration, the world economic downturn which started in the USA in 2007 as a result of sub-prime mortgage problems had a more significant impact on the African macroeconomic fundamentals (Jose and Massa, 2009). The impact which is attributed to a decrease in the price of commodity, unimpressive inflow of funds, low net income from abroad, decrease in foreign assistance and falling portfolio investment. This, as a result, leads to a low export proceeds, negative shocks on current account and balance of payment with a negative pressure on investment, Gross Domestic Product (GDP), and employment (IMF, 2008). The impacts of the global financial crisis on African countries through their macroeconomic imbalances were felt mostly by the asset markets (Stocks and Real estate markets). For example, stock market volatility has increased since the outset of the crisis, and wealth losses took place in African major stock exchanges.

In Egypt and Nigeria, the stock market indices declined by about 57 percent between March 
2008 and March 2009. Kenya, Mauritius, Zambia, and Botswana also recorded significant losses (CIA, 2008). Before the global financial crisis, the Nigerian stock prices had appreciated significantly. The periods between 2002 and 2007, the Nigerian stock market value increased to a peak of 12.6 trillion (World Bank, 2009). This boom actually led to an investment rush by both domestic and foreign investors. However, following the global financial meltdown, foreign direct investors started to move their funds from the capital market. Removal of investors funds from the capital market consequently affect the size of the market with a decrease in the prices of stock in Nigeria. In addition, the real estate growth rates of $33 \%, 21 \%$, and $31 \%$ were recorded for Nigeria, Ghana, and Tanzania respectively in 2007 but fell to $-25 \%,-11 \%$, and 3\% in 2009 for the same countries as a result of the global financial crisis (Rothacher, 2015).

In the light of the above, economic theory suggests that fluctuations in macroeconomic factors as a result of economic crisis or financial instability will affect asset prices through its impact on the expected future dividend stream (Harvey, 1995). Therefore, an understanding of the relationship between macroeconomic determinants and asset prices is very important for investors and policymakers.

Several research works have tested the relationship between macroeconomic determinants and asset prices. However, most of the past empirical evidence about these relationships are not sufficient enough. For example, a lot of research works most especially in Africa such as Osamuonyi and Evbayiro-Osagie (2012), Frimpong (2009), Asaolu and Ogunmuyiwa (2011), Ochieng and Oriwo (2012) only investigated the reaction of stock prices to macroeconomic variables, while the expected reactions of real estate price to macroeconomic variables have not been sufficiently and robustly reported. Meanwhile, analyses of historical asset price data show that real estate prices compared to stock prices are more prone to boom and bust cycles. According to the IMF World Economic Outlook (2003), the equity price bubble occurs on an average of every thirteen years, prolongs for two years, and results in about four percent loss in Gross Domestic Product. Real estate price bubble in its own case occurs less frequently, but last nearly twice as long and lead to output losses that are twice as large. Hence, the real estate prices become a more efficient index of price bubbles than equity prices. In this regard, this research work studies the behaviors of real estate prices alongside the stock prices so as to have a robust representation in the asset market.

Moreover, most of the past research works, particularly in Africa [Osamuonyi and Evbayiro-Osagie (2012), Olukayode and Akinwande (2009), Adam and Tweneboah (2008), Kyereboah, Anthony and Kwame (2008), Muthike and Sakwa (2011) etc] used an overall sample period for their studies and assumed that the causal relationship between macroeconomic variables and asset prices are identical over the business cycle regimes. Although, the works of Narayan and Narayan (2012) divided their studies' periods into two business cycle regimes to account for asymmetric effects. However, their studies were majorly based on the behavior of stock price only and the works were centered on Asian countries and not Africa. The use of an overall sample period by the past researchers in Africa has actually resulted in their research works generating conflicting and inconsistent results due to the omission of asymmetric effects of macroeconomic shocks on the behavior of asset 
prices. Whereas, most of the time, asset price reactions to macroeconomic shocks vary according to the state of the economy. Garcia and Schaller (2002) argue that some macroeconomic variables have stronger real effects in the period of recessions than in expansions. In this sense, this research work corrects these anomalies by avoiding the mixture of business cycle regimes; this is done by segregating the periods under this study into Pre-Global Financial Crisis Years and Global Financial Crisis years.

Moreover, most of the past research works in Africa analyzed the relationship between macroeconomic variables and asset prices in isolation of the global macroeconomic fundamentals without taking into consideration the effect of the growing integration of markets. In order to overcome the limitations of the past research works in this regard, this study incorporates both domestic and global macroeconomic variables into the Structural Vector Autoregressive model to determine the real behaviors of the asset price.

The rest of the paper is organized as follows: Section 2 discusses relevant empirical literature. Section 3 deals with the theoretical framework and estimation techniques. Section 4 presents and discusses results while section 5 concludes.

\section{Review of Empirical Literature}

Chaudhuri and Smiles (2004) used Impulse Response Function (IRF) analysis and Forecast Error Variance Decomposition (VDC) analysis to examine the relationship between the Australian real stock price index and real measures of aggregate economic activity which include the broad money supply (M3), GDP, private personal consumption expenditures and the world oil price index. Using quarterly data from 1960 to 1998, the study showed a long-run relationship between all variables. However, IRF and VDC analyses showed weak evidence for the relationship between the Australian real stock price index and all the macroeconomic variables included in the analysis.

Narayan and Narayan (2012) employed OLS and GARCH model to assess how the United States macroeconomic conditions affect the stock of seven Asian countries (China, India, Philippines, Malaysia, Singapore, Thailand, and South Korea). Using daily data which was divided into the pre-crisis period (pre-August,2007) and crisis period (post-August, 2007), they found that short-term interest rate has a statistically insignificant effect on stock returns for all countries except the Philippines in the crisis period and except for China, depreciation had a statistically significant negative effect on stock returns. Their results also showed that a long-run relationship exists among the variables in four countries (India, Malaysia, Philippines, and Thailand) in the pre-crisis period. The implication of this is that financial crisis had dampened the relations between the prices of stock and macroeconomic variables.

Mak and Choy (2012) employed a reduced-form equilibrium model to investigate the possible sources of real estate investment differentials among 22 provinces, five autonomous regions, and four municipalities of the People's Republic of China. The model was estimated using panel data from 2001 to 2006, yielding a total of 186 observations. The results of this study suggested that demographics, economic, and planning factors are the major determinants that cause real estate investments to vary among Chinese regions. The paper 
finally suggested that the Chinese government should focus on several policy parameters in order to achieve a more balanced state of real estate investment across Chinese regions.

Tsatsaronis and Zhu (2004) used a Vector Autoregressive (VAR) model to study the property prices for 17 industrialized economies between 1970 and 2003. The VAR model used by the authors includes five endogenous variables besides house price growth namely: GDP growth rate, inflation rate, the real short-term interest rate, equity prices, and bank lending rate. The results of their study revealed that economic growth, inflation and interest rates, bank lending, and equity prices have a significant explanatory impact on house price movements.

Osamuonyi and Evbayiro-Osagie (2012) employed the Vector Error Correction Model (VECM) to study the short-run dynamics of the stock market index from the Nigerian economy. By using yearly data of interest rates, inflation rates, exchange rates, fiscal deficit, GDP, and money supply from 1975 to 2005, the study revealed that money supply (M2) has a significant but negative relationship with the stock market index in both the short-run and long-run.

Asaolu and Ogunmuyiwa (2011) used the ADF test, Granger causality test, cointegration, and Error Correction Method (ECM) to examine the impact of macroeconomic variables on the Average Share Price (ASP) of the Nigerian stock market. Yearly data were collected from the period of 1986 to 2007 on the inflation rate, foreign capital inflow, external debt, fiscal deficit, exchange rate, investment, industrial output, and ASP of the Nigerian stock market. The findings of the study showed that a feeble link exists between Average Share Price and macroeconomic factors in Nigeria and concluded that Average Share Price was not an efficient index of macroeconomic fundamentals in the Nigerian economy. The findings further revealed that a long-term relation exists between Average Share Price and macroeconomic variables.

Olukayode and Akinwande (2009) employed the ADF test, Engle-Granger cointegration test, and Error Correction model to investigate the long-run and short-run shocks from macroeconomic variables on the Nigerian Capital Market. Annual data were collected from 1984 to 2007 on some variables like CPI, broad money supply (M2), treasury bill rate, real output growth (RGDP), exchange rate, and all share index of the Nigerian stock exchange. The results of the study showed that macroeconomic variables had a short-term effect on stock prices. The study further revealed that the money supply, real GDP, exchange rate and inflation rate have more impacts on the stock prices during the period under investigation.

Adam and Tweneboah (2008) used the cointegration test and Error Correction model to examine the effect of macroeconomic variables on the Ghanaian stock market between 1980 and 2004. The results of the cointegration test showed that Treasury Bills had a negative and significant relationship on the stock market returns, foreign direct investment had a positive and significant relationship while inflation and exchange rate have a negative but insignificant relationship on stock market returns. The study therefore concluded that macroeconomic fundamentals such as interest rate, inflation rate, foreign direct investment, and exchange rate have a significant impact on the stock market in Ghana. 
Frimpong (2009) employed the Johansen cointegration mechanism to examine the links among stock prices, interest rate, inflation rate, exchange rates and money supply in the Ghana stock market. Monthly data were collected from November 1990 to December 2006. The results of the findings showed that all the macroeconomic variables (except the exchange rate) had negative and significant effects on stock prices.

Kyereboah, Anthony, and Kwame (2008) used Johansen Cointegration and ECM to examine how macroeconomic indicators affect the performance of the Ghana stock market using quarterly time-series data covering the period of 1991 to 2005. They found that lending rates from deposit money banks have an adverse effect on stock market performance and particularly serve as a major hindrance to business growth in Ghana. The Inflation rate was found to have a negative effect on stock market performance.

Olalere (2006) examined the relationship between macroeconomic variables and stock market behaviors in the South African stock market. For this purpose, annual time series data were collected from the period of 1990 to 2004. Using the estimation technique of Vector Error Correction mechanism and Johansen Cointegration test, the results of the study revealed that inflation had a significant negative impact on share prices, while long-term interest rates had positive impacts on the stock prices. The exchange rate was found to have no significant effect on share prices but had a significant and negative impact on market capitalization. The study further revealed that US interest rates had a greater effect on the South African stock market than South Africa's own domestic interest rates.

Ochieng and Oriwo (2012) investigated the impact of macroeconomic variables on the Kenyan stock prices. For this purpose, annual time series data were collected from the period of 2008 to 2012 on the variables like stock prices, Treasury Bill Rate, inflation rate and lending rate. By using Cointegration and Error Correction Method, the findings of the study revealed that the 91-day T-Bill rate has a negative relationship with stock prices in Kenya while inflation has a weak positive relationship with the stock prices in Kenya.

Muthike and Sakwa (2011) employed Cointegration and ECM to examine the real macroeconomic determinants of the stock prices in Kenya. Using annual time series data from 1980 to 2008, the results of the study found that the Treasury Bill rate, money supply, and exchange rates were positive while inflation rates and GDP exhibited a negative relationship. The study further revealed that the stock prices in Kenyan stock market had significant relations with all macroeconomic variables.

Orman (2003) employed Cointegration and Error Correction Model to examine the impact of real interest rates on the performance of the Egyptian stock market. Using annual time series data spanning from 1980 to 2000, the results of the study showed significant long-term and short-term relations between the variables which indicates that the real interest rates affect the stock market performance in Egypt.

Gupta and Kabundi (2010) employed a Factor Augmented Vector Autoregressive (FAVAR) to investigate the impact of monetary policy (Interest Rate) on real house price growth in South Africa. For this purpose, Quarterly data were collected from the period of 1980Q1 to 2006Q4. 
The results from Impulse Response Functions showed that house price was negatively related to monetary policy shocks.

Muli (2011) used multiple regression analyses to examine the relationship between housing prices and credit in Kenya. This research employed a quarterly data from 2006q1 to 2010q4. The study therefore concluded that changes in housing prices are positively and significantly related to the long-term evolution of mortgage credit. The causality results revealed that the real estate market does not really affect housing price changes rather, changes in housing prices do affect the amount of real estate financing.

Ojetunde, Popoola, and Kemiki (2011) employed a Vector Autoregressive Model to assess the effect of macroeconomic shocks on residential property rents in Nigeria. Using quarterly data from 1980: Q1 to 2005: Q4, the results from the study suggested that macroeconomic shocks explain $20 \%$ fluctuations in the residential property rents. They, therefore, concluded that the effect of a standard deviation shock from the real GDP, exchange rates and interest rates on the residential property rents is an indication that the residential property rents adjust slowly to changes in macroeconomic events.

\section{Research Method}

\subsection{Theoretical Framework}

An investigation into the effect of macroeconomic variables on the asset prices in this study is rested on the International Arbitrage Pricing Model (IAPM), which was propounded by Bilson, Brailsford, and Hooper (2004). IAPM is the multifactor asset pricing model used to determine both global and domestic risk factors on asset prices. This model is a revised version of the original Arbitrage Pricing Theory (APT) which was proposed by Ross (1976).

\section{Analysis of Arbitrage Pricing Theory}

The APT model assumes that the return to the ith asset, Rit, can be written as:

$$
R_{i t}=\propto_{i}+b_{i j} f_{j}+\ldots \ldots \ldots \ldots . . . . b_{i k} f_{k}+e_{i t}
$$

Where: $R_{i t}$ is the return on asset $i, \propto_{i}$ is the expected return of asset, $f_{j}$ are the asset returns sensitivity to factor loadings, $b_{i j}$ are the factor loadings and $e_{i t}$ is a random variable.

Equation 1 above implies that the returns on asset are influenced by factor sensitivity which could be positive or negative. However, the main problem associated with the APT model is that it is silent about which events or factors are likely to influence asset prices (Elton, Gruber, and Brown, 2003). Several empirical works focused on the attempts to determine the factors through two different strands: First, is by using pre-specified observed macroeconomic factors and second, is by assuming that, a priori, the factors were unknown. Roll and Ross (1986) adopted a factor analysis to extract the risk factors for equities from the United State Economy.

Azeez and Yonoezawa (2003) put forward a two-step test by which the APT approach can be estimated. The first step involves the use of time-series data to estimate a set of 
macroeconomic factors that can affect asset returns. The second step is to regress the sample mean returns on the factor loading in a cross-section regression. However, some of the macroeconomic variables set forth by these researchers to proxy risk factors in the APT model are mostly based on domestic macroeconomic variables. No effort was made to incorporate the global framework into the risk factors on asset returns.

Although, in a global framework, containing countries with so many disparities, it is more difficult to decide the common sources of risk factors on asset returns (Buckberg, 1995). In order to better address this problem, Bilson, Brailsford, and Hooper (2004) extend the Arbitrage Pricing Theory (APT) to International Arbitrage Pricing Model (IAPM).

Analysis of International Arbitrage Pricing Model (IAPM)

Bilson, Brailsford and Hooper (2004) integrated two sets of macroeconomic variables to serve as potential risk factors. The first set is composed of global macroeconomic variables which are prescribed as follows:

$$
R_{i t}=\alpha_{i}+\sum_{m=1}^{N} \beta_{i m} F_{m t}^{w}+\varepsilon_{i t}
$$

Where:

$\boldsymbol{R}_{\boldsymbol{i t}}$ is the return for the $\boldsymbol{i t h}$ country at time $\mathrm{t}$

$\boldsymbol{\alpha}_{i} \quad$ is the Risk-free rate of return

$\boldsymbol{B}_{\boldsymbol{i m}}$ is the exposure of the $\boldsymbol{i t h}$ asset to the $\boldsymbol{m} \boldsymbol{t h}$ (Global) risk factor at time $\mathrm{t}$

$\boldsymbol{F}_{\boldsymbol{m} \boldsymbol{t}}^{\boldsymbol{w}}$ is the realization of the $\boldsymbol{m} \boldsymbol{t h}$ (Global) risk factor at time $\mathrm{t}$

$\varepsilon_{i t}$ is the residual term for the country $\boldsymbol{i}$ at time $\mathrm{t}$

The equation 2 above indicates a model of asset return variation for country i, where country $\mathrm{i}$ is perfectly integrated with world financial markets. In this model, it is assumed that there are $\mathrm{N}$ - factors that are able to account for the variation in the returns for country i. Asset returns are also assumed to be a relation to $\mathrm{N}$-global risk factors.

The second set is composed of domestic macroeconomic variables which is presented as follows:

$$
R_{i t}=\alpha_{i}+\sum_{j=1}^{k} \gamma_{i j} f_{i j t}^{L}+\mu_{i t}
$$

Where:

$\boldsymbol{R}_{\boldsymbol{i t}}$ is the return for the $\boldsymbol{i t h}$ country at time $\mathrm{t}$

$\boldsymbol{\alpha}_{\boldsymbol{i}}$ is the Risk-free rate of return

$\boldsymbol{\gamma}_{\boldsymbol{i} \boldsymbol{j}}$ is the exposure of the $\boldsymbol{i t h}$ asset to the $\boldsymbol{j} \boldsymbol{t h}$ (domestic) risk factor

$\boldsymbol{f}_{\boldsymbol{i j t}}^{L}$ is the realization of the $\boldsymbol{j t h}$ (domestic) risk factor in the $\boldsymbol{i t h}$ country at time $\mathrm{t}$

$\boldsymbol{\mu}_{i t}$ is the residual term for country $\boldsymbol{i}$ at time $\mathrm{t}$ 
The equation 3 above denotes an alternative model that is developed for asset returns in a country that is perfectly segmented from global markets. The variation in asset returns for Country $i$ is assumed to be able to be explained by $\mathrm{K}$ - domestic risk factors.

Some of the empirical studies in the area of financial asset market integration propose two major findings for the emerging asset markets. First, emerging asset markets tend to be only partially integrated (Harvey, 1995). Second, the level of integration appears to vary over time Bekaert and Harvey (1995). Based on these findings, it is quite pertinent to regard both global and local risk factors as important determinants of asset return variation.

Therefore, according to Bilson, Brailsford and Hooper (2004), the equation 4 below, models asset returns as a function of exposure to both global and domestic factors:

$$
R_{i t}=\alpha_{i}+\sum_{m=1}^{N} \beta_{i m} F_{m t}^{w}+\sum_{j=1}^{k} \gamma_{i j} f_{i j t}^{L}+\varepsilon_{i t}
$$

\subsection{Sources of Data}

The data set for this study consists of quarterly secondary data spanning from 1990Q1 to 2016Q4. For the purpose of examining the asymmetric and short-term dynamics in the macroeconomics and asset price relationships, and also in line with the work of Narayan and Narayan (2012), this study segregates the period under review into Pre-Global Financial Crisis Years (1990Q1 - 2006Q4) and Global Financial Crisis years (2007Q1 - 2016Q4). The idea behind this is for the former to represent the boom period while the latter represents the depression period. Although, there had been some other economic crises across the globe during these periods, but the 2007/2008 global economic and financial crisis is believed to have been the worst since the great depression of 1930s (World Bank, 2009), of which African countries were greatly affected and the spill-over effects are still felt by most African countries up till 2016 which this study actually covers.

The data on domestic macroeconomic variables namely: Real Interest Rate (RINTR) and real GDP growth rate (RGDPgr) are sourced from the World Bank database, data on Exchange Rate (EXR), Stock Prices (SP), and Real Estate Prices (REP) of the four selected African countries are sourced from United Nation Statistical Bulletin. Data on the global macroeconomic variables namely: World oil price (WOP) and World Real GDP growth rate (WRGDPgr) and US Federal Fund Rate (FFR) are sourced from International Financial Statistics of the IMF database. Apart from RINTR, RGDPgr, WRGDPgr, and FFR, all other variables (REP, SP, EXR, and WOP) are expressed in their natural logarithms.

\subsection{Estimation Techniques}

This study employs the Structural VAR model. What really informs the choice of the SVAR model against the conventional VAR model (i.e Cholesky decomposition) is that the identification approach of the latter assumes only a recursive method. This recursive method has been adjudged as being exposed to wrong causal ordering, particularly when emphasis is on monetary shocks (Gottshalk, 2001). In addition, SVAR is employed in this study because of the fact that not all variables react immediately to shocks as in the case of recursive VAR. 
Evidence from past researchers indicated that many variables respond slowly to shocks because of financial deepening (Elbourne, 2008). All these anomalies can be conveniently taken care of by the non-recursive SVAR model. In a bid to complement the appropriateness of the SVAR model, some preliminary tests are employed in this study. The stationarity of time series properties of all variables is tested using the Im Persaran and Shin (IPS) panel unit root test. This is very important so as to enable us to decide whether the SVAR model should be specified using variables in levels or first difference (Bjornland and Leitemo, 2009). Also, the error correction-based panel cointegration test proposed by Westerlund (2007) is employed to confirm the evidence of cointegration relationships among all the variables that enter into the SVAR model. Lastly, the Breusch-Pagan LM test is used to confirm the possibility of cross-member correlation in the series that can necessitate bootstrapping in the cointegration test (Persyn and Westerlund, 2008).

\section{Model Set-up}

This study uses an eight-variable SVAR model. This model is similar to the one used by Li, Iscan and Xu (2010), Raghvan, Silvapulle and Athanasopoulos (2012) and Pirovano (2012). The model captures four selected African countries based on their asset market values for the periods under investigation, and each of them represents its respective region in Africa. Nigeria represents West Africa; South-Africa represents South Africa. Kenya represents East Africa, while Egypt represents North Africa. What really informs the choice of these four African countries is that they have the largest asset market capitalization in their respective regions and show a significant level of trade openness to other developed economies (Nile Capital Management, 2012). In this regard, the policy implication arising from this study for the four selected African countries can serve as a general conceptualization for all other African countries.

The model assumes that each of the selected African economies follows a structural-form equation as shown below:

$$
A(L) X_{t}+B(L) Y_{t}=V_{t}
$$

Where $\boldsymbol{A}(\boldsymbol{L})$ and $\boldsymbol{B}(\boldsymbol{L})$ are the $\boldsymbol{n} \times \boldsymbol{n}$ and $\boldsymbol{n} \times \boldsymbol{k}$ matrix polynomial of the lag operator respectively. $\boldsymbol{X}_{\boldsymbol{t}}$ is a $\boldsymbol{n} \times \mathbf{1}$ vector of exogenous foreign variables of interest. $\boldsymbol{Y}_{\boldsymbol{t}}$ is a $\boldsymbol{k} \times \mathbf{1}$ vector of endogenous domestic variables which are grouped into two blocks, that is, vector of policy variables and vector of non-policy variables. $\boldsymbol{V}_{\boldsymbol{t}}$ is an $\boldsymbol{n} \times \mathbf{1}$ vector of structural disturbances with 0 mean and $\operatorname{Var}\left(\mathrm{V}_{\mathrm{t}}\right)=$ $\Psi$ (where $\Psi$ denotes a diagonal matrix)

The elements of the diagonal matrix represent variances of structural disturbances. The estimation of the reduced-form equation of the structural model (1) is estimated putting into a consideration that the structural disturbances are mutually uncorrelated. The equation is presented below:

$$
Y_{t}=C(L) X_{t}+D(L) Y_{t}+U_{t}
$$

Where $\boldsymbol{C}(\boldsymbol{L})$ and $\boldsymbol{D}(\boldsymbol{L})$ are the matrix polynomial of the lag operator and $\boldsymbol{U}$ is a vector of 
the VAR residuals with 0 mean and $\operatorname{Var}\left(\boldsymbol{U}_{\boldsymbol{t}}\right)=\boldsymbol{\Sigma}$. Considering the reduced-form estimation, we could estimate the parameters in the structural-form equation in many ways. However, the estimation of structural parameters requires the imposition of some restrictions on the elements of matrix A. By normalizing $\boldsymbol{n} \times \mathbf{1}$ diagonal elements of matrix A to ones (i.e unity), we need at least $\boldsymbol{n}\left[\frac{(\boldsymbol{n}-\mathbf{1})}{2}\right]$ to attain identification. We impose the restrictions based on past empirical findings and economic theory.

\section{Model Identification: Non- Recursive Approach}

The imposition of restrictions on the contemporaneous matrix of structural parameter in this research work follows the work of Li et al (2010), Raghvan et al (2012) and Pirovano (2012). In this model, the exogenous vector $\left\{\boldsymbol{X}_{\boldsymbol{t}}: \boldsymbol{W R G D P g r , F F R , W O P}\right\}$ is assumed to be a foreign block. The foreign variables are incorporated to account for exogenous change in the global economic stance. The endogenous vector $\left\{\boldsymbol{Y}_{\boldsymbol{t}}: \boldsymbol{R G D P} \boldsymbol{g r}, \boldsymbol{E X R}, \boldsymbol{R I N T R}, \boldsymbol{S P}, \boldsymbol{R E P}\right\}$ is assumed to be a domestic block, which comprises both policy and non-policy variables. Policy variables compose of $\{\boldsymbol{R I N T R , E X R}\}$ while non-policy variables consist of $\{\boldsymbol{R G D P g r}, \boldsymbol{S P}, \boldsymbol{R E P}\}$ which are target variables. The equation 7 below therefore summarizes the non-recursive identification approach as follows:

\begin{tabular}{|c|c|c|c|c|c|c|c|c|c|c|}
\hline$[U W R G D P g r$ & & 1 & $\mathbf{0}$ & $a 13$ & $\mathbf{0}$ & $\mathbf{0}$ & $\mathbf{0}$ & $\mathbf{0}$ & $\mathbf{0}$ & {$[\varepsilon W R G D P g r$} \\
\hline$U F F R$ & & $a 21$ & 1 & $a 23$ & $\mathbf{0}$ & $\mathbf{0}$ & $\mathbf{0}$ & $\mathbf{0}$ & $\mathbf{0}$ & $\varepsilon F F R$ \\
\hline$U W O P$ & & $\mathbf{0}$ & $\mathbf{0}$ & 1 & $\mathbf{0}$ & $\mathbf{0}$ & $\mathbf{0}$ & $\mathbf{0}$ & $\mathbf{0}$ & $\varepsilon W O P$ \\
\hline$U R G D P g r$ & $=$ & $a 41$ & $\mathbf{0}$ & $a 43$ & 1 & $\mathbf{0}$ & $\mathbf{0}$ & $a 47$ & $\mathbf{0}$ & $\varepsilon R G D P g r$ \\
\hline$U E X R$ & & $a 51$ & $a 52$ & $a 53$ & $a 54$ & 1 & $a 56$ & $\mathbf{0}$ & $a 58$ & $\varepsilon E X R$ \\
\hline U RINTR & & $a 61$ & $a 62$ & $a 63$ & $a 64$ & $a 65$ & 1 & $a 67$ & 0 & $\varepsilon R I N T R$ \\
\hline$U S P$ & & 0 & $a 72$ & $a 73$ & $a 74$ & $a 75$ & $a 76$ & 1 & $a 78$ & $\varepsilon S P$ \\
\hline$U R E P$ & & $a 81$ & $a 82$ & $a 83$ & 0 & $a 85$ & 0 & 0 & 1 & $\varepsilon R E P$ \\
\hline
\end{tabular}

Where $U^{W R G D P g r}, U^{F F R}, U^{W O P}, U^{R G D P g r}, U^{E X R}, U^{R I N T R}, U^{S P}, U^{R E P}$ are the structural disturbances

On the endogenous variables respectively and $\varepsilon^{W R G D P G R}, \varepsilon^{F F R}, \varepsilon^{W O P}, \varepsilon^{R G D P g r}, \varepsilon^{E X R}, \varepsilon^{R I N T R}, \varepsilon^{S P}, \varepsilon^{R E P}$ are reduced-form residual that describe the unanticipated movements of each regressor respectively.

The first three rows in equation 7 relate to World real GDP growth rate (WRGDPgr), United States Federal Fund Rate (FFR), and World oil price (WOP), which represent external macroeconomic variables. Similar to the work of Li et al (2010), we assume that domestic shocks do not affect the external sector variables, but domestic variables are assumed to be affected by external shocks. Following the work of Raghvan et al (2011), we allow RGDPgr in the fourth row to be affected by WRGDPgr, WOP, and SP while monetary policy variables like EXR and RINTR do not affect it. The reason behind this assumption is the fact that the outputs of the firms do not react to the shocks emanating from the financial or monetary policies due to adjustment costs. In the fifth row which represents the exchange rate, we assume that it is driven by all variables except the stock price. Kim and Roubini (2000) posited that the exchange rate is a monetary variable that responds rapidly to all information. We assume that the real interest rate in the sixth row is affected by all variables except the 
real estate price. The last two rows relate to stock price and real estate price, which represent target variables. Following the work of Pirovano (2012), we assume that the stock price is affected by all variables except WRGDPgr. The reason for this assumption is that stock prices are forward-looking and at a given time quickly respond to new information available in the market. We assume that the real estate price is driven by all the external macroeconomic variables and the exchange rate while the remaining domestic variables do not affect it.

Table 1. DESCRIPTION OF VARIABLES

\begin{tabular}{|c|c|}
\hline VARIABLES & DESCRIPTION \\
\hline Real Estate Prices (REP) & $\begin{array}{l}\text { For uniformity sake, House price Index is used as proxy for Real Estate Prices for } \\
\text { the selected African countries. These are obtained in domestic currencies and } \\
\text { converted to US dollars (US\$). REP is expressed in its natural logarithm }\end{array}$ \\
\hline Stock Prices (SP) & $\begin{array}{l}\text { All Share Index is used as proxy for Stock Prices. These are equally obtained in } \\
\text { domestic currencies and converted to US dollars (US\$). SP is expressed in its } \\
\text { natural logarithm }\end{array}$ \\
\hline $\begin{array}{l}\text { Real Interest Rate } \\
\text { (RINTR) }\end{array}$ & $\begin{array}{l}\text { Real Interest Rate represents the lending rate adjusted for inflation in the selected } \\
\text { African countries. }\end{array}$ \\
\hline $\begin{array}{l}\text { Real GDP growth rate } \\
\text { (RGDPgr) }\end{array}$ & $\begin{array}{l}\text { Real GDP growth rate represents the change in each country's GDP from one period } \\
\text { of time (usually a year) to the next after being adjusted for inflation. }\end{array}$ \\
\hline Exchange Rate (EXR) & $\begin{array}{l}\text { Exchange Rates represent the price of each country's currency in terms of another } \\
\text { currency. These are expressed as units of local currencies to US dollars. EXR is } \\
\text { expressed in its natural logarithm }\end{array}$ \\
\hline $\begin{array}{l}\text { US Federal Fund Rate } \\
\text { (FFR) }\end{array}$ & $\begin{array}{l}\text { US Federal Fund Rate represents the US short-term interest rate at which depository } \\
\text { institutions borrow from and lend to each other their reserve balances, usually } \\
\text { overnight on an uncollateralized basis. }\end{array}$ \\
\hline $\begin{array}{l}\text { World Real GDP growth } \\
\text { rate (WRGDPgr) }\end{array}$ & $\begin{array}{l}\text { World Real GDP growth rate represents the combined changes in Gross Domestic } \\
\text { Product of all countries in the world after being adjusted for inflation. }\end{array}$ \\
\hline World Oil Price (WOP) & $\begin{array}{l}\text { World Oil Price represents the bench mark price for purchases of oil worldwide and } \\
\text { it was measured in US dollars per barrel. WOP is expressed in its natural logarithm }\end{array}$ \\
\hline
\end{tabular}

\section{Results and Discussions}

\subsection{Results}

\subsubsection{Panel Unit Root Tests results}

This aspect assesses the stationarity properties of the data series, in order to know the individual feature of the variables. This is done by testing the order of integration of the variables which is also referred to as the unit root test. It is very important to determine the order of integration before embarking on the SVAR model specification as this would help us to ascertain whether the SVAR model should be specified using variables in levels, first difference, or otherwise adopting VECM (Bjornland and Leitemo, 2009). Therefore, for the purpose of determining the stationary of the variables, this research work uses the Im Pesaran and Shin (IPS) unit root test as shown in the table below: 
Table 2. Unit Root Test (Im Pesaran and Shin)

\begin{tabular}{|l|l|l|l|}
\hline \multirow{2}{*}{ Variables } & \multicolumn{3}{|l|}{ Unit Root Test (IPS) } \\
\cline { 2 - 4 } & t-statistics & Probability-value & Integration order \\
\hline SP & -5.4328 & $0.0000^{* * *}$ & $\mathrm{I}(1)$ \\
\hline REP & -3.1564 & $0.0021^{* * *}$ & $\mathrm{I}(1)$ \\
\hline RINTR & -5.3872 & $0.0000^{* * *}$ & $\mathrm{I}(1)$ \\
\hline RGDPGR & -4.1103 & $0.0052^{* * *}$ & $\mathrm{I}(1)$ \\
\hline EXR & -5.0543 & $0.0000^{* * *}$ & $\mathrm{I}(1)$ \\
\hline FFR & -4.9042 & $0.0000^{* * *}$ & $\mathrm{I}(1)$ \\
\hline WRGDPGR & -5.1232 & $0.0000^{* * *}$ & $\mathrm{I}(1)$ \\
\hline WOP & -3.8973 & $0.0013^{* * *}$ & $\mathrm{I}(1)$ \\
\hline
\end{tabular}

Source: Researcher's Computation

$(* * *)$ refers to $1 \%$ level of significance. Trends and constant term are composed in each model.

$\mathrm{SP}=$ Stock Price, $\mathrm{REP}=$ Real Estate Price, $\mathrm{RINTR}=$ Real Interest Rate, $\mathrm{RGDPgr}=$ Real GDP growth rate, EXR $=$ Exchange Rate, FFR $=$ US Federal Fund Rate, WRGDPgr $=$ World Real GDP growth rate, WOP $=$ World Oil Price

The table 2 above depicts the results of IPS panel unit root tests. The results confirm that all the series do not have their stationarities at levels, while the stationarities are attained at the first difference. The implication is that all the variables are integrated of order one, I(1). In this regard, all variables are entered in the SVAR model in their first differences.

\subsubsection{Error-Correction Based Panel Cointegration Test}

Since the stationarities of all the variables have been attained at the first difference, then it is quite pertinent to ascertain the cointegrating relationship among the variables. This is necessary as it will enable us to know the appropriateness in the use of the SVAR model or otherwise, the adoption of vector error correction mechanism (VECM). Sims (1980) proposed that a VECM should be used in a circumstance whereby the precise cointegrating relationship is known and specified. He further suggested that if the evidence of a cointegration is not achievable among the variables, then the use of the VAR/SVAR model is appropriate as it yields consistent estimates.

The panel cointegration test model for this study is designed in two-panel forms. Stock Price (SP) is the first dependent variable that represents "PANEL A" while Real Estate Price (REP) is the second dependent variable that forms "PANEL B". Considering these two dependent variables (i.e SP and REP) along with their independent variables (i.e Rintr, RGDPgr, Exr, FFR, WRGDPgr, and WOP) the Error-Correction Based Panel Cointegration tests are conducted on the two panels accordingly as follows:

\section{Error-Correction Based Panel Cointegration Test (PANEL A)}

In this part, there is a build-up of four tests, in a bid to test for a long-run relationship. The 
tests are carried out on the basis of asymptotic distribution and cross-sectional dependence. The Asymptotic distribution results for the tests are depicted as follows:

Table 3. Asymptotic Distribution Value: Westerlund Panel Cointegration Test: (PANEL A)

\begin{tabular}{|l|l|l|l|}
\hline Statistics & Value & Z-value & Probability-value \\
\hline $\mathrm{Gt}$ & -0.786 & 5.321 & 1.000 \\
\hline $\mathrm{Ga}$ & -0.632 & 4.761 & 1.000 \\
\hline $\mathrm{Pt}$ & -1.921 & 5.102 & 1.000 \\
\hline $\mathrm{Pa}$ & -0.231 & 4.503 & 1.000 \\
\hline
\end{tabular}

Source: Researcher's Computation

NOTE: Both Gt and Ga test the null hypothesis that there is no cointegration across the entire cross-sectional units against the alternative hypothesis that there is cointegration in at least one cross-sectional unit. Also, both $\mathrm{Pt}$ and $\mathrm{Pa}$ test the null hypothesis that there is no cointegration for the whole panel against the alternative hypothesis that there is cointegration for all the cross-sectional units. Trends and constant terms are composed in the tests, while the selection of lag and lead lengths are on the basis of Akaike Information Criterion and Bartlett Kernel Window. Width is designed on the basis of $4\left[\frac{T}{100}\right] \frac{2}{n}$.

The results in table 3 strongly show an acceptance of the null hypothesis of no long-run relationship between the Stock Prices and Macroeconomic Variables in the selected African countries. The results therefore indicate the appropriateness in the use of SVAR model in this study.

Table 4. Correlation Matrix of Residuals (PANEL A)

\begin{tabular}{|l|l|l|l|l|l|l|l|l|}
\hline & $-\mathrm{e} 1$ & $-\mathrm{e} 2$ & $-\mathrm{e} 3$ & $-\mathrm{e} 4$ & $-\mathrm{e} 5$ & -e6 & -e7 & -e8 \\
\hline -e1 & 1.0000 & & & & & & & \\
\hline -e2 & -0.0720 & 1.0000 & & & & & & \\
\hline -e3 & 0.0761 & 0.0432 & 1.0000 & & & & & \\
\hline -e4 & -0.0652 & 0.3254 & 0.2014 & 1.0000 & & & & \\
\hline -e5 & 0.1432 & -0.1872 & 0.2651 & -0.1108 & 1.0000 & & & \\
\hline -e6 & -0.0132 & -0.1454 & -0.0652 & -0.1082 & -0.1234 & 1.0000 & & \\
\hline -e7 & 0.0264 & 0.6542 & 0.1542 & 0.8231 & 0.0254 & -0.1652 & 1.0000 & \\
\hline -e8 & -0.0662 & -0.2521 & 0.2311 & -0.2431 & -0.2981 & 0.0425 & -0.3551 & 1.000 \\
\hline
\end{tabular}

Source: Researcher's Computation

Breusch-Pagan LM test of Independence: Chi $2(29)=142.762, \operatorname{Pr}=0.0000$, Ho: There is no cross-sectional dependence.

Table 4 above shows the results of the cross-sectional dependence test. From the results, it is confirmed that there is presence of cross-sectional dependence, because, the probability value 
(0.0000) is less than a 5 per cent level of significance. The presence of cross-sectional dependence in the results above further justifies the use of the SVAR model to test each cross-sectional unit separately. The reason behind this is that cross-sectional dependence is mainly caused by the presence of common factors among the units, thereby leading to cross-member correlation. For example, African countries are known to have a common characteristic of being an emerging economy, thereby giving room for the tendency of sharing similar factors among themselves. However, the responses of these cross-sectional units to the common factor shocks might be at varying degrees due to different social norms, economic effects, and independent preferences that characterize each of the cross-sectional unit (Pesaran, 2013).

In a bid to get an effective and a reliable cointegration results, and also because of the presence of cross-sectional dependence in the series, it is necessary to test for bootstrapping. Testing for bootstrapping will enhance a strong probability-value, considering the availability of cross-member correlation (Persyn and Westerlund, 2008). The panel cointegration test as a result of cross-sectional dependence is shown in the table 5 below.

Table 5. Panel Cointegration Test considering Cross-Sectional Dependence (PANEL A)

\begin{tabular}{|l|l|l|l|l|}
\hline Statistics & Value & Z-Value & Probability-Value & Robust P-Value \\
\hline $\mathrm{Gt}$ & -0.973 & 4.713 & 1.000 & 0.742 \\
\hline $\mathrm{Ga}$ & -0.652 & 5.341 & 1.000 & 0.752 \\
\hline $\mathrm{Pt}$ & -1.623 & 6.432 & 1.000 & 0.842 \\
\hline $\mathrm{Pa}$ & -0.542 & 5.054 & 1.000 & 0.654 \\
\hline
\end{tabular}

Source: Researcher's Computation.

NOTE: Both Gt and Ga test the null hypothesis that there is no cointegration across the entire cross-sectional units against the alternative hypothesis that there is cointegration in at least one cross-sectional unit. Also, both $\mathrm{Pt}$ and $\mathrm{Pa}$ test the null hypothesis that there is no cointegration for the whole panel against the alternative hypothesis that there is cointegration for all the cross-sectional units. Trends and constant terms are composed in the tests, while the selection of lag and lead lengths are on the basis of Akaike Information Criterion and Bartlett Kernel Window. Width is designed on the basis of $4\left[\frac{T}{100}\right] \frac{2}{n} .400$ bootstrap replications are included

From the results in table 5 above, it is confirmed that the cointegration in all the four tests accept the null hypothesis of no cointegration, even, in spite of the consideration for cross-sectional dependence. This is a further evidence that there is no long-term co-movement between macroeconomic variables and Stock Prices of the selected African countries and the results further confirm the appropriateness in the use of SVAR model in this study.

\section{Error-Correction Based Panel Cointegration Test (PANEL B)}

In this aspect, both asymptotic distribution and cross-sectional dependence tests are conducted on the Real Estate Prices. The asymptotic distribution results on real estate price 
are first of all presented as follows.

Table 6. Asymptotic Distribution Value: Westerlund Panel Cointegration Test: (PANEL B)

\begin{tabular}{|l|l|l|l|}
\hline Statistics & Value & Z-Value & Probability-Value \\
\hline $\mathrm{Gt}$ & -1.432 & 2.762 & 1.000 \\
\hline $\mathrm{Ga}$ & -0.978 & 5.123 & 1.000 \\
\hline $\mathrm{Pt}$ & -1.621 & 4.402 & 1.000 \\
\hline $\mathrm{Pa}$ & -1.052 & 4.191 & 1.000 \\
\hline
\end{tabular}

Source: Researcher's Computation.

NOTE: Both Gt and Ga test the null hypothesis that there is no cointegration across the entire cross-sectional units against the alternative hypothesis that there is cointegration in at least one cross-sectional unit. Also, both $\mathrm{Pt}$ and $\mathrm{Pa}$ test the null hypothesis that there is no cointegration for the whole panel against the alternative hypothesis that there is cointegration for all the cross-sectional units. Trends and constant terms are composed in the tests, while the selection of lag and lead lengths are on the basis of Akaike Information Criterion and Bartlett Kernel Window. Width is designed on the basis of $4\left[\frac{T}{100}\right] \frac{2}{n}$.

Like the results for "PANEL A", the results in table 6 equally exhibit an acceptance of null hypothesis of no cointegration. This therefore implies that there is no long-run relationship between the Real Estate Prices and Macroeconomic Variables in the selected African countries. We now proceed to the cross-sectional dependence test, the results of which are presented in the table 7 below:

Table 7. Correlation Matrix of Residuals (PANEL B)

\begin{tabular}{|l|l|l|l|l|l|l|l|l|}
\hline & $-\mathrm{e} 1$ & $-\mathrm{e} 2$ & $-\mathrm{e} 3$ & $-\mathrm{e} 4$ & $-\mathrm{e} 5$ & $-\mathrm{e} 6$ & $-\mathrm{e} 7$ & $-\mathrm{e} 8$ \\
\hline -e1 & 1.0000 & & & & & & & \\
\hline -e2 & -0.0620 & 1.0000 & & & & & & \\
\hline -e3 & 0.0325 & 0.0982 & 1.0000 & & & & & \\
\hline -e4 & -0.0123 & 0.2431 & 0.1542 & 1.0000 & & & & \\
\hline -e5 & 0.0128 & -0.1764 & 0.1872 & -0.1972 & 1.0000 & & & \\
\hline -e6 & -0.0763 & -0.1872 & -0.1652 & -0.1972 & -0.1802 & 1.0000 & & \\
\hline -e7 & 0.0643 & 0.6542 & 0.1251 & 0.6532 & 0.1543 & -0.0162 & 1.0000 & \\
\hline -e8 & -0.1872 & -0.2431 & 0.1762 & -0.1322 & 0.6524 & 0.0321 & 0.3412 & 1.000 \\
\hline
\end{tabular}

Source: Researcher's Computation

Breusch-Pagan LM test of Independence: Chi 2(29) $=142.912, \operatorname{Pr}=0.0000$, Ho: There is no cross-sectional dependence.

Just like the results in 'PANEL A', the results in table 7 show the presence of cross-member correlation. Hence, there is need for bootstrapping so as to obtain a reliable cointegration test 
result. Therefore, the results of panel cointegration with bootstrapping are shown below.

Table 8. Panel Cointegration test considering Cross-Sectional Dependence (PANEL B)

\begin{tabular}{|l|l|l|l|l|}
\hline Statistics & Value & Z-Value & Probability-Value & Robust P-Value \\
\hline $\mathrm{Gt}$ & -1.113 & 2.341 & 1.000 & 0.752 \\
\hline $\mathrm{Ga}$ & -0.982 & 4.612 & 1.000 & 0.432 \\
\hline $\mathrm{Pt}$ & -2.542 & 4.642 & 1.000 & 0.541 \\
\hline $\mathrm{pa}$ & -0.761 & 3.452 & 1.000 & 0.452 \\
\hline
\end{tabular}

Source: Researcher's computation.

NOTE: Both Gt and Ga test the null hypothesis that there is no cointegration across the entire cross-sectional units against the alternative hypothesis that there is cointegration in at least one cross-sectional unit. Also, both $\mathrm{Pt}$ and $\mathrm{Pa}$ test the null hypothesis that there is no cointegration for the whole panel against the alternative hypothesis that there is cointegration for all the cross-sectional units. Trends and constant terms are composed in the tests, while the selection of lag and lead lengths are on the basis of Akaike Information Criterion and Bartlett

Kernel Window. Width is designed on the basis of $4\left[\frac{T}{100}\right] \frac{2}{n} .400$ bootstrap replications are included.

The table 8 above shows that no cointegration is confirmed in all the four tests. This is because Gt, Ga, Pt and Pa all show acceptance of the null hypothesis of no cointegration. This further confirm that despite taking into consideration the cross-sectional dependence, there is still no long-run relationship between Real Estate Price and Macroeconomic variables in the selected African countries.

\subsubsection{Structural Vector Autoregressive (SVAR) Model}

The presence of cross-member correlation in the two panel cointegration tests conducted earlier further justifies the use of Structural VAR estimation technique in this study to examine how each cross-sectional unit responds differently to common factor shocks. Moreover, for the purpose of achieving the objective of examining the asymmetric effects of macroeconomic variable shocks on asset prices in this study, Structural Vector Autoregressive estimation is conducted on the two business cycle regimes, that is, Pre-Global Financial Crisis Years (1990-2006) and Global Financial Crisis Year (2007-2016). Thus, the Impulse Response functions of the Structural VAR model are presented as follows:

\section{Results of SVAR Impulse Response Functions}



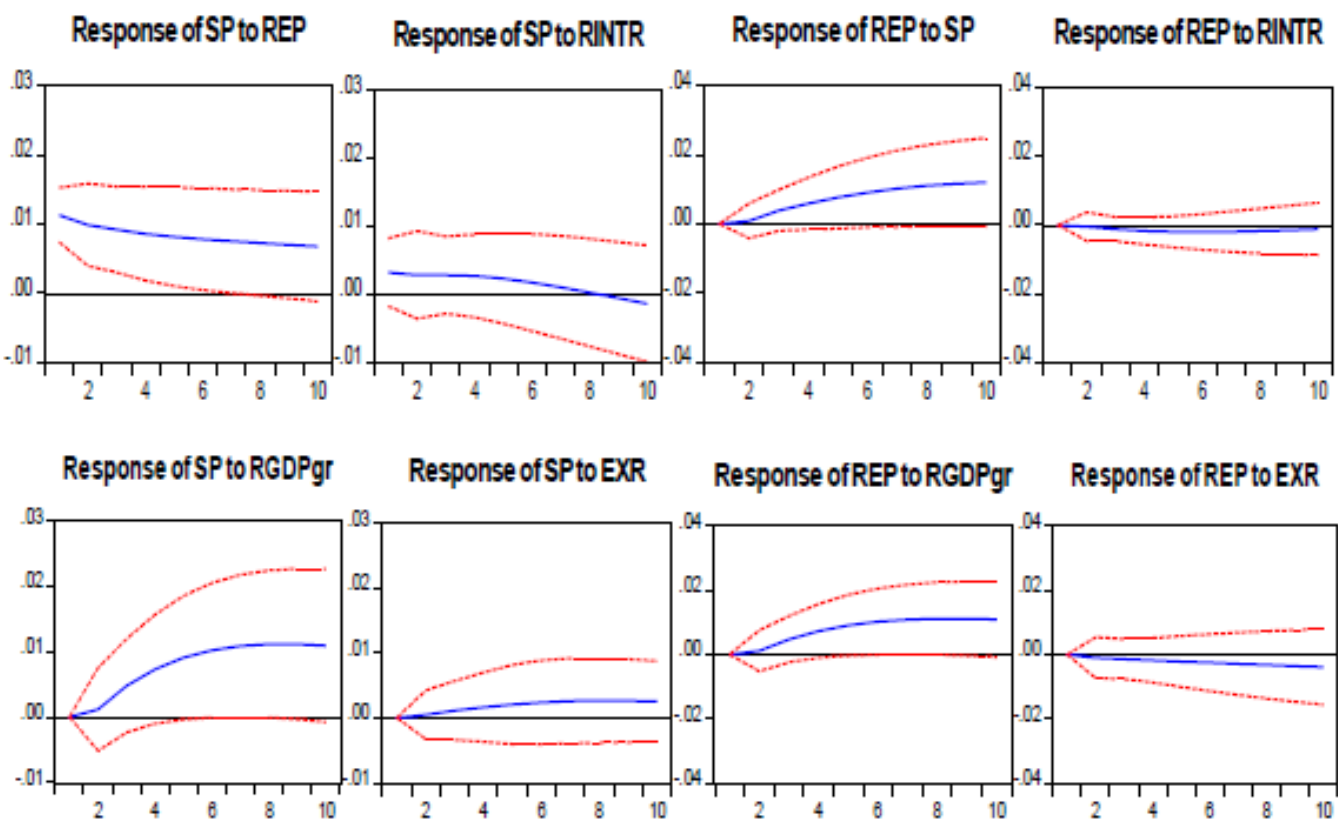

Response of SP to FFR Response of SP to WRGDPgr Response of REP to FFR Response of REP to WRGDPgr

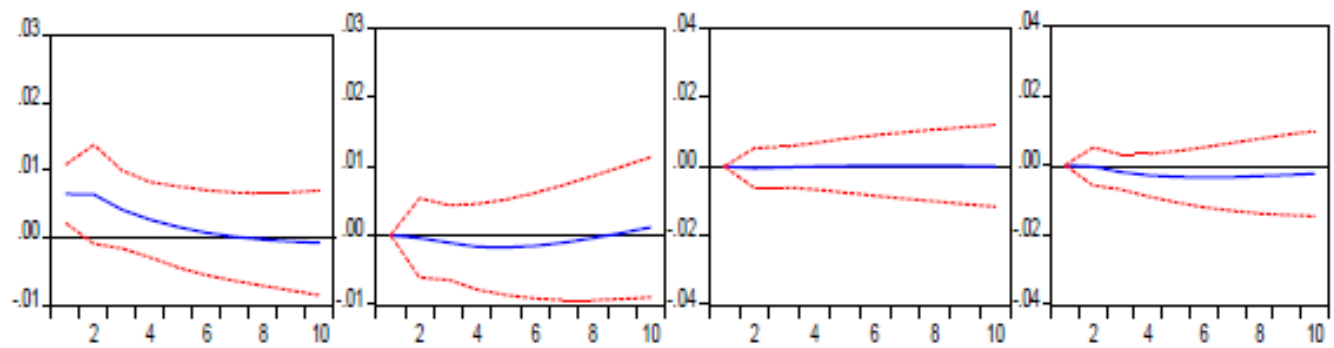

Response of SP to WOP

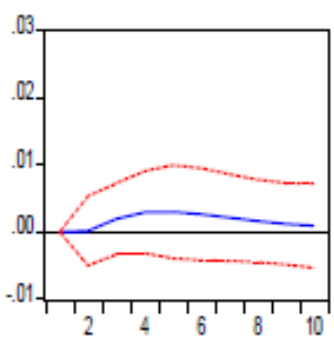

Response of REP to WOP

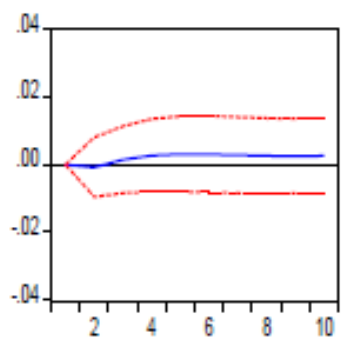

Figure 1a. Regime Dependent Impulse Response Functions for Nigeria Pre-Global Financial Crisis Years (1990-2006) 


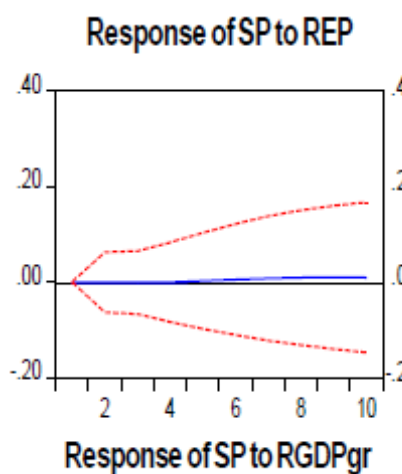

\section{Response of SP to RINTR}

Response of REP to SP

Response of REP to RIIITR
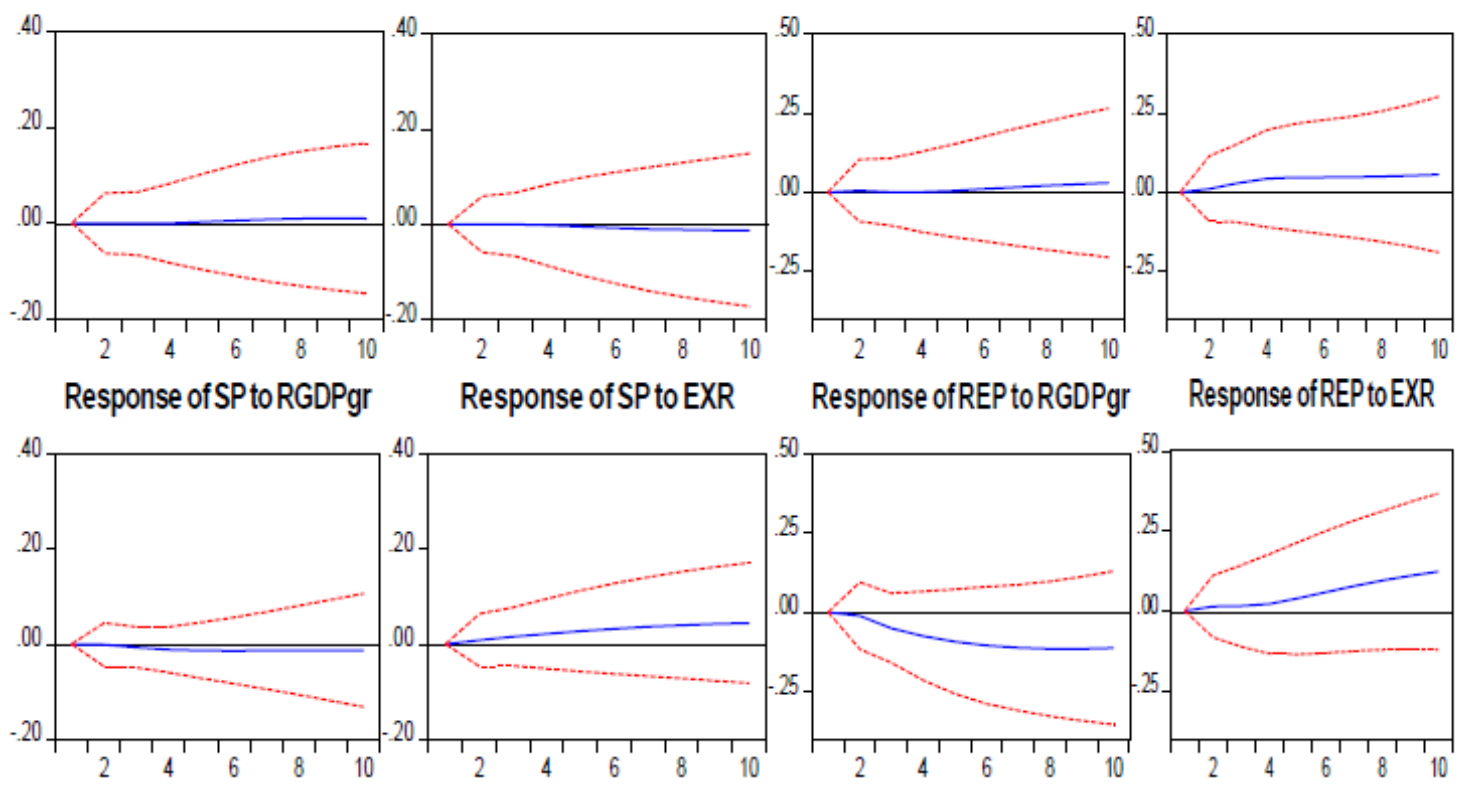

Response ofSPtoFFR
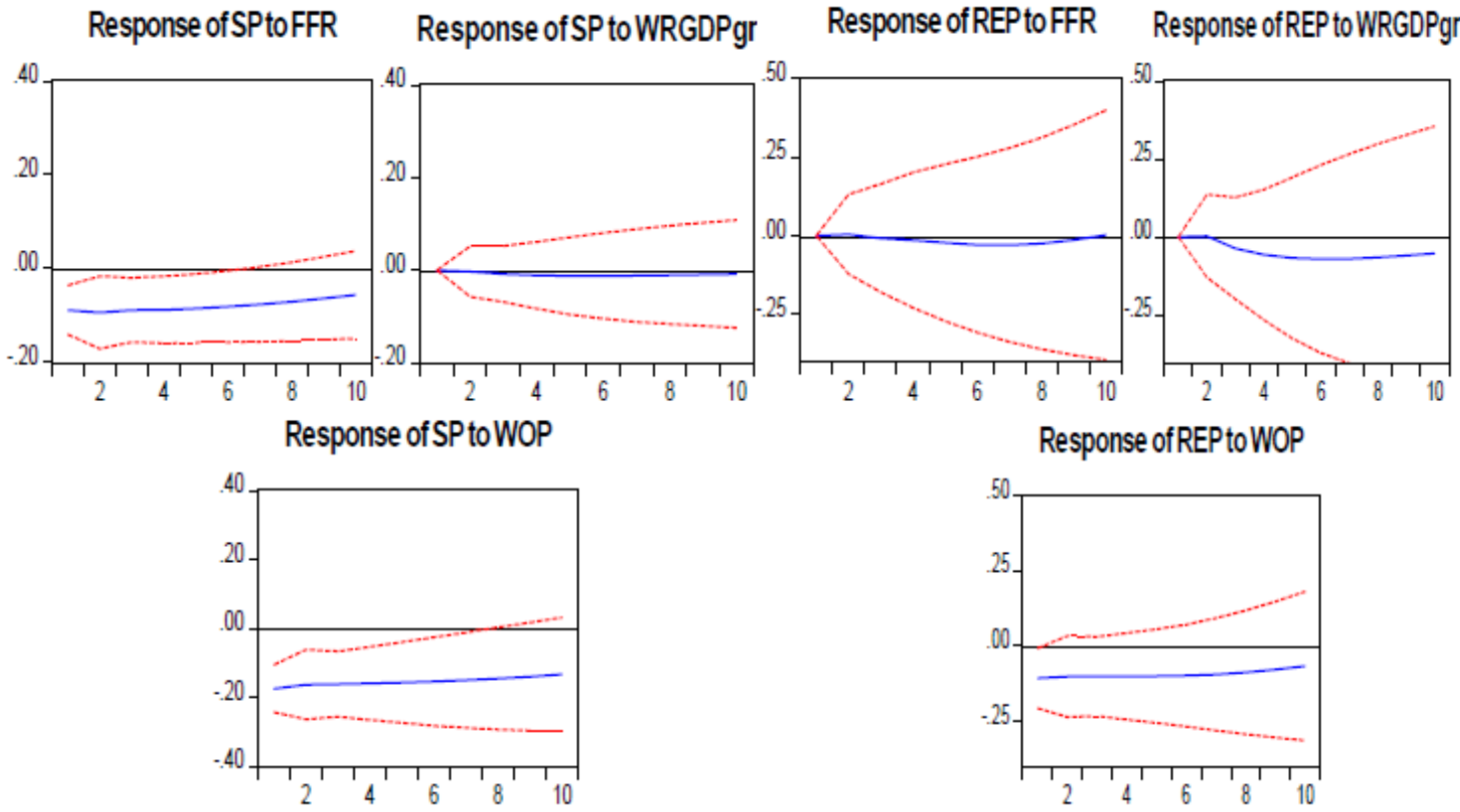

Figure 1b. Global Financial Crisis Years (2007-2016)

The first two columns of figures $1 \mathrm{a}$ and $1 \mathrm{~b}$ display the impulse responses of stock price to a standard deviation shock in the macroeconomic variables in Nigeria during both expansion and depression periods respectively. While the last two columns of the same figure 1a and $1 \mathrm{~b}$ depict the responses of real estate price to a standard deviation shock in the macroeconomic variables in Nigeria during both expansion and depression periods respectively. Results from the figures show that a standard deviation shock from both stock and real estate price produce the same positive and significant impacts on each other during the expansion period. However, the case is quite different in the crisis period as stock and real estate prices now have positive but insignificant responses to a shock from real estate and stock prices 


\section{Macrothink

respectively. It is equally observed that the response of stock price to the shock from real interest rate is positive up till the 9th period but later diverged negatively away below the equilibrium during the expansion period, while the response of real estate price to the shock from real interest rate is negative but insignificant during the same expansion period. But the reverse is the case in the crisis period as the shocks from real interest rates exert negative but insignificant impacts on stock price while the same shocks from real interest rates have positive and significant impacts on real estate price.

As expected, the impacts of shocks from RGDPgr on both stock and real estate prices are positive and significant during the expansion period but negative during the crisis period. Shocks from EXR exert positive and significant impacts on stock price during the expansion period while the same shocks from EXR have negative and significant impacts on real estate price. The case is now different during the crisis period as the shocks from EXR now have positive and significant impacts on both stock and real estate prices. The responses of both stock and real estate prices to the shocks from FFR are positive but insignificant during the expansion period. But the reverse is the case during the crisis period as the shocks from FFR now inflict negative impacts on both stock and real estate prices, though the impacts are more significant on stock price than the real estate price. In addition, the responses of both stock and real estate prices to the shocks from WRGDPgr are negative during the expansion and crisis period, though the impact of the shock is most pronounced on REP during the crisis period. Lastly, the shocks from WOP have positive but insignificant impacts on both stock and real estate prices during the expansion period. But this is not the case during the crisis period as the shocks from WOP now exert negative and significant impacts on both stock and real estate prices. 

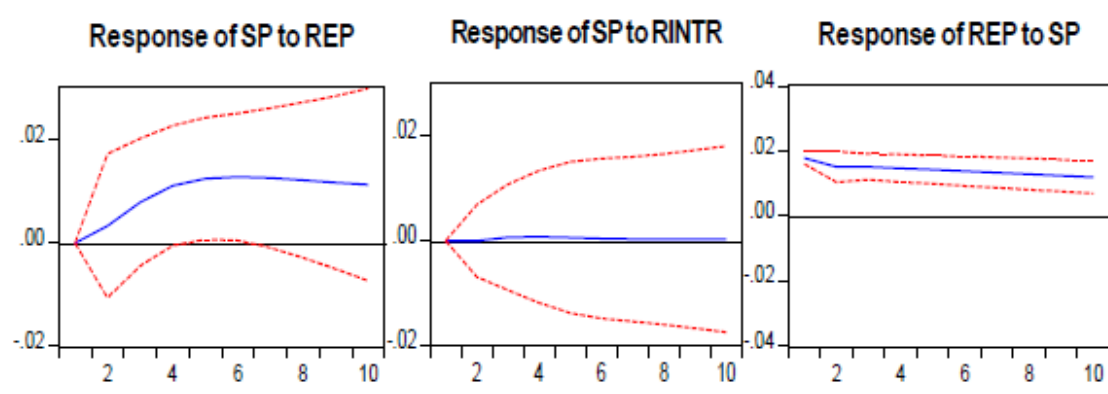

Response of REP to RINTR

Response of SP to RGDPgr

Response of SP to EXR

Response of REP to RGDPgr
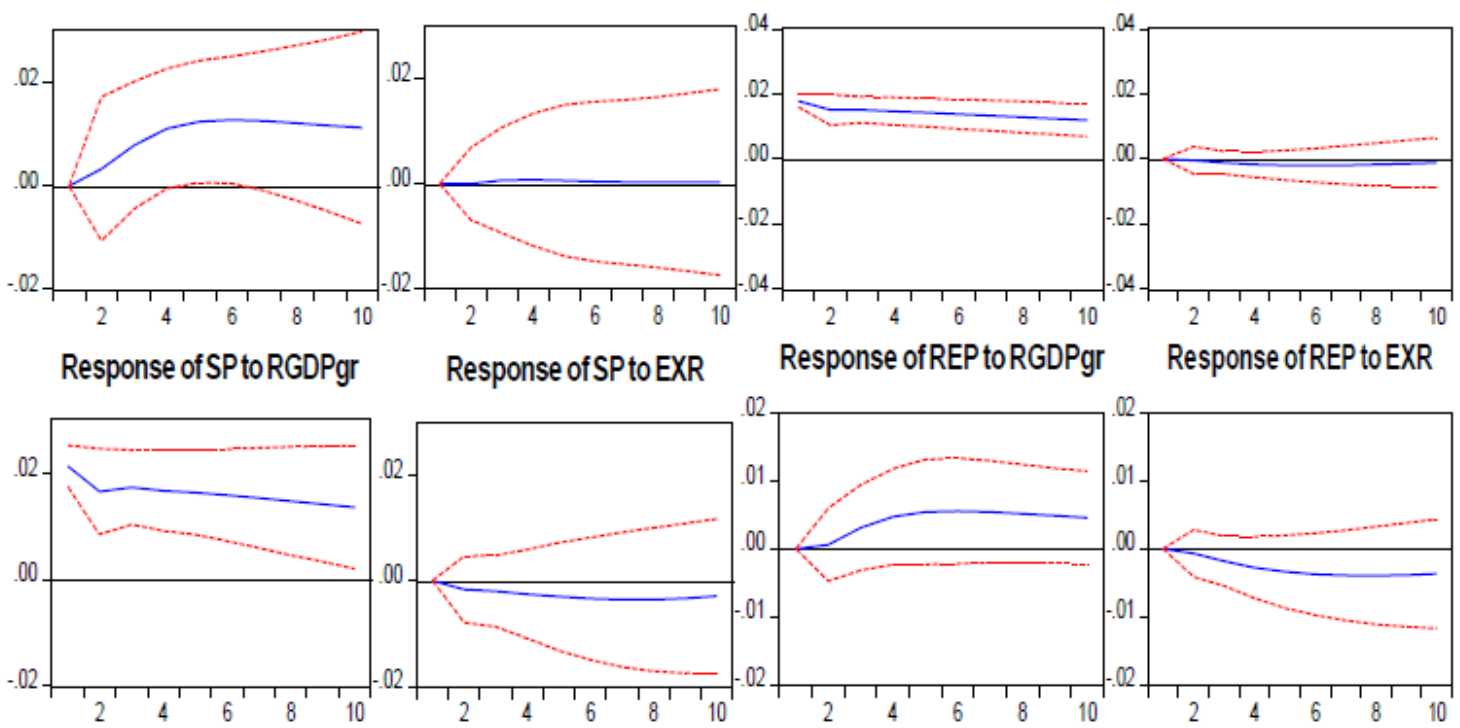

Response ofSPtoFFR

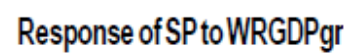

Response of REP to FFR

Response ofREP to WRGDPgr
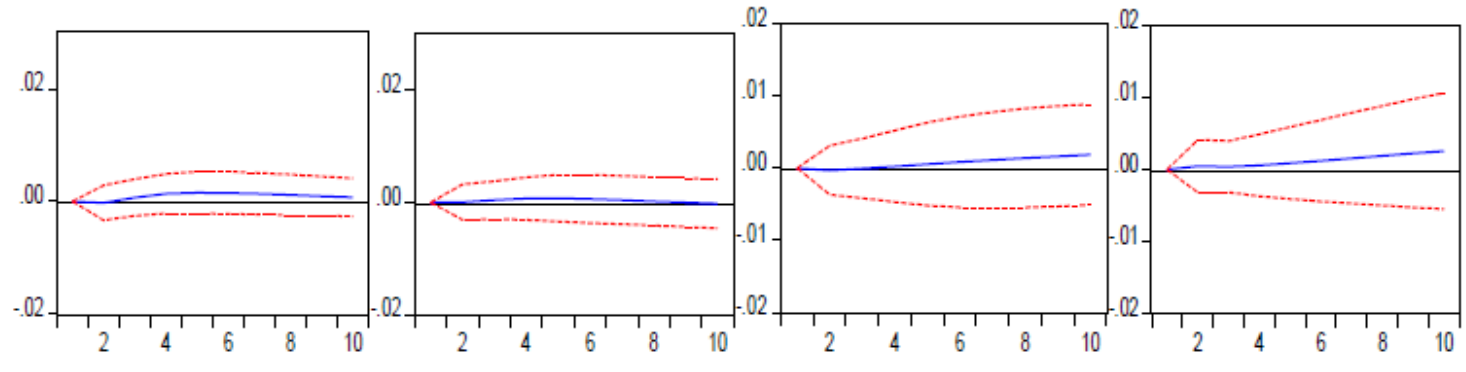

Response of SP toWOP

Response of REP toWOP
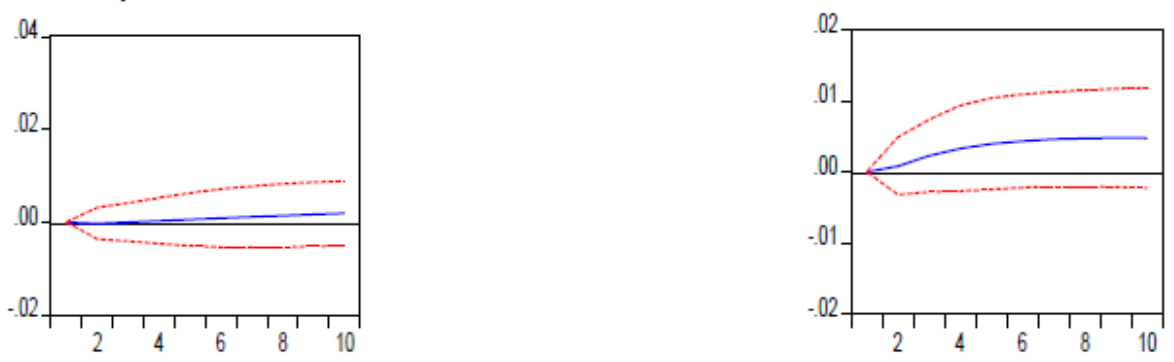

Figure 2a. Regime Dependent Impulse Response Functions for Egypt Pre-Global Financial Crisis Years (1990-2006) 

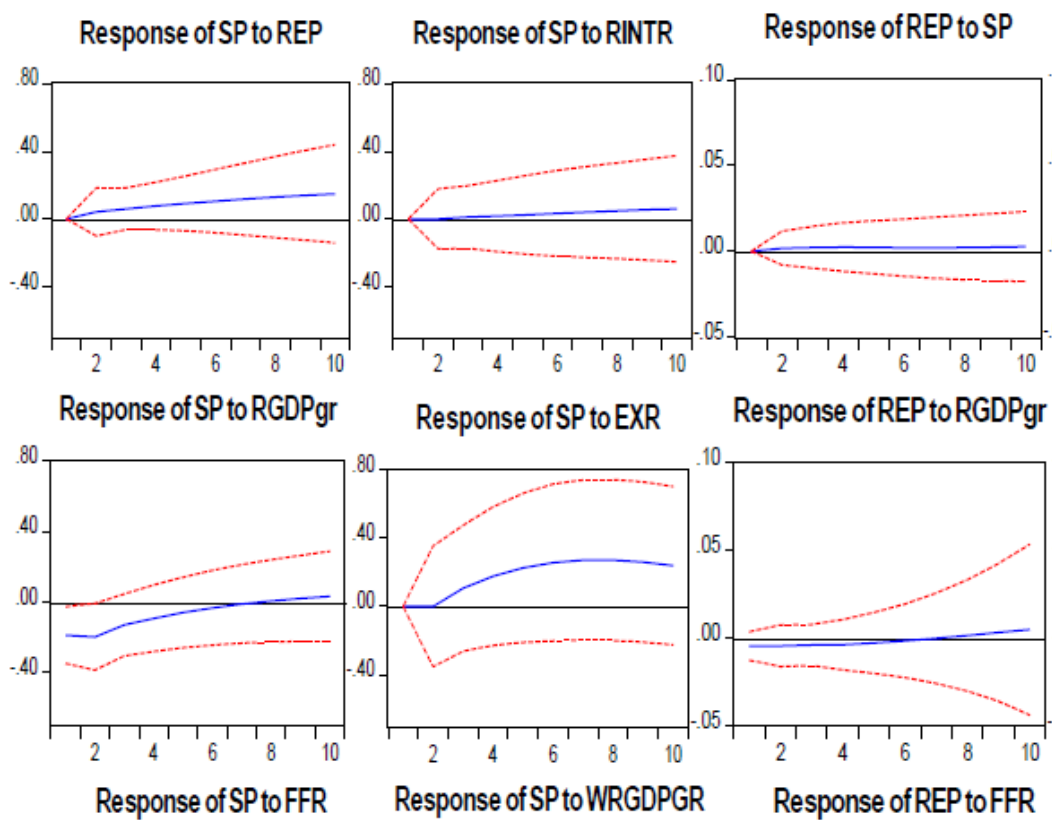

Response of SP to EXR
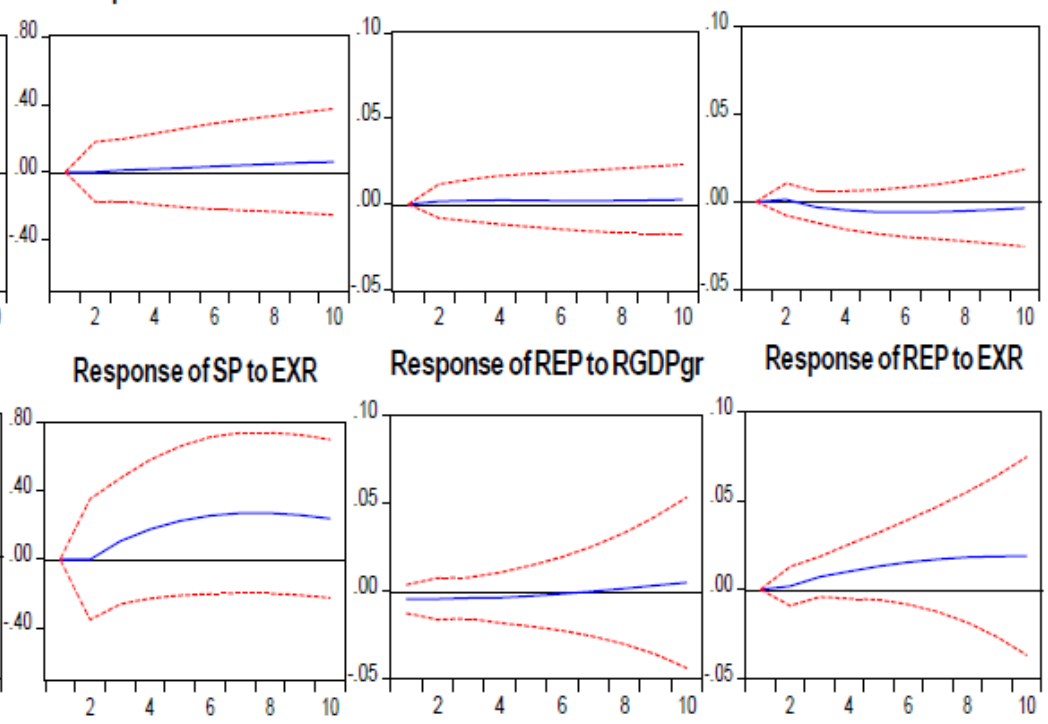

Response of REP to EXR
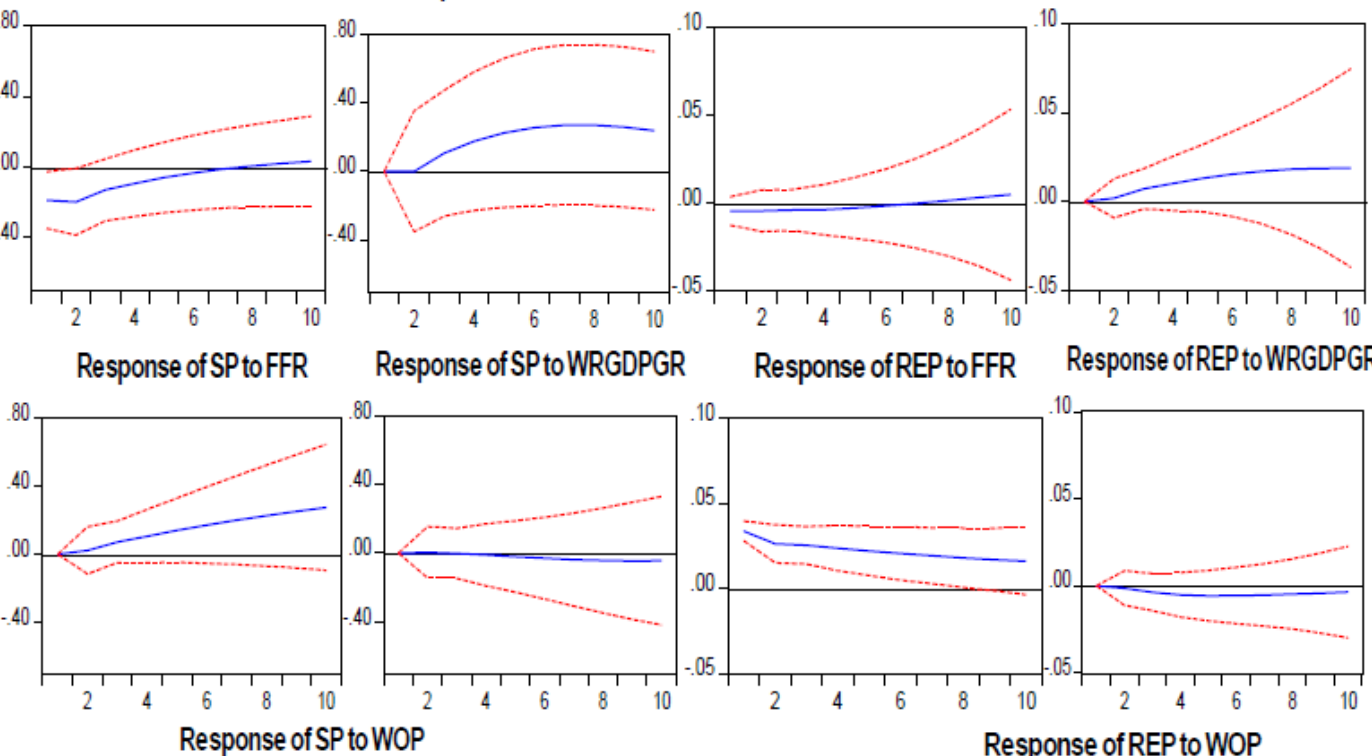

Response of SP toWRGDPGR
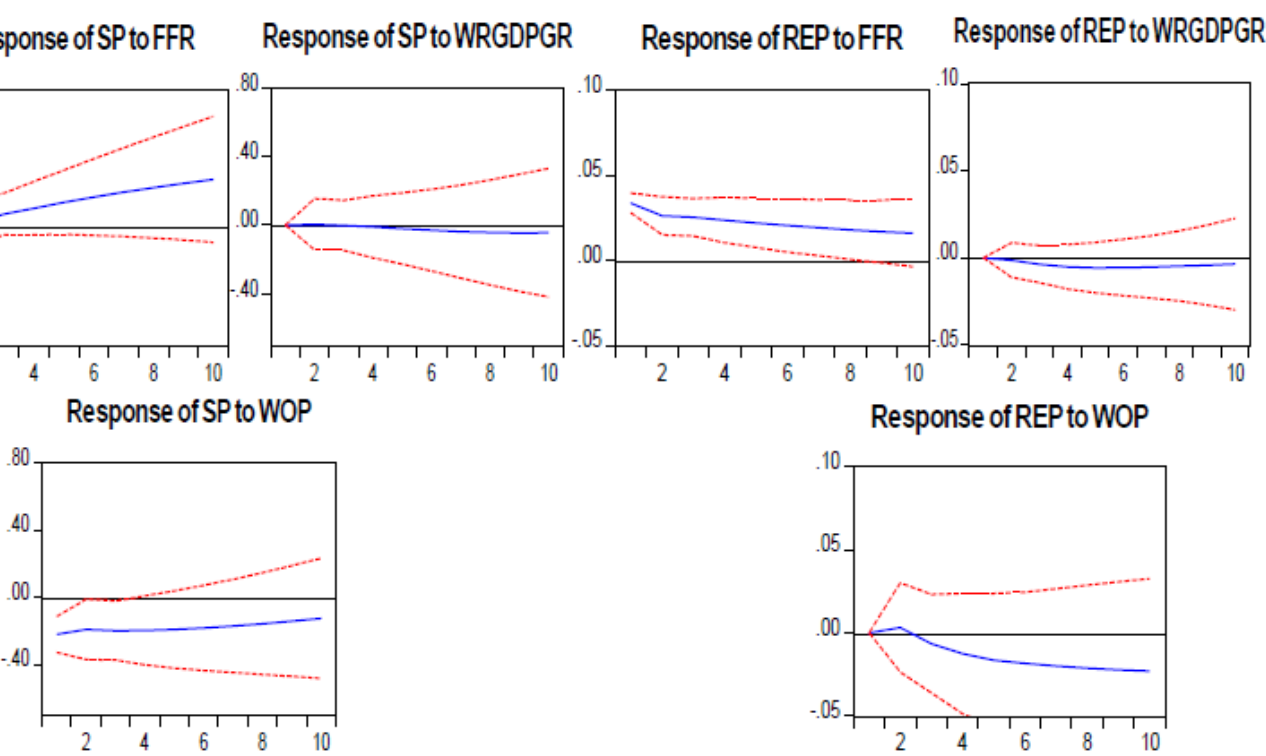

Figure 2b. Global Financial Crisis Years (2007-2016)

The SVAR impulse response function results in figures $2 a$ and $2 b$ show the responses of stock and real estate prices to a standard deviation shock from the macroeconomic variables in Egypt during the expansion and crisis periods. Similar to the results previously analyzed for Nigeria, a standard deviation shocks from both stock and real estate prices show the same positive and significant impacts on each other during the expansion period in Egypt. The same positive but insignificant impacts are equally recorded for the two asset prices during the crisis period. A critical observation of this result also shows that a standard deviation shocks from RINTR exert positive but insignificant impacts on both stock and real estate prices during the expansion period. Shocks from RINTR now have negative but insignificant impacts on real estate price while the same shocks from RINTR still maintain positive but insignificant impacts on the stock price. 


\section{Macrothink}

Business and Economic Research

ISSN 2162-4860

2021, Vol. 11, No. 2

Moreover, the responses of both stock and real estate prices to the shocks from RGDPgr are positive and significant during the expansion period. The case is quite different during the crisis period as the shocks from RGDPgr now inflict negative but insignificant impacts on the two asset prices (stock and real estate prices). A standard deviation shock from EXR has negative and significant impacts on both stock and real estate prices during the expansion period, while the responses of both stock and real estate prices to the shocks from EXR are now positive and significant during the crisis period. Also, shocks from FFR, WRGDPgr, and WOP have positive but insignificant impacts on both stock and real estate prices during the expansion period. But a different case is recorded during the crisis period as the shocks from WRGDPgr and WOP now have negative impacts on both stock and real estate prices, though the impacts of WOP shocks are more significant on the two asset prices. Also, the shocks from FFR still maintain positive but significant impacts on both stock and real estate prices during the crisis period.

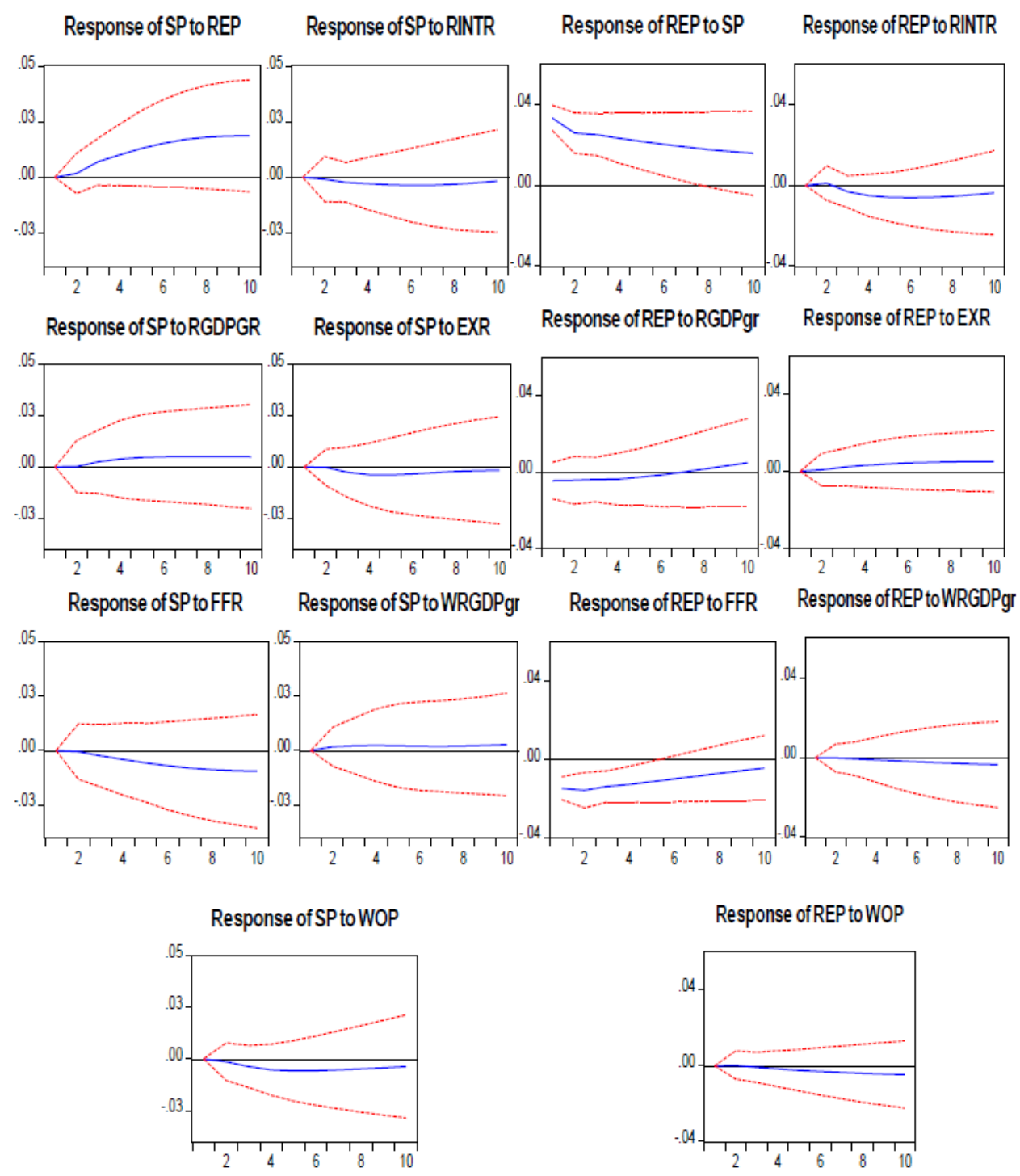

Figure 3a. Regime Dependent Impulse Response Functions for South-Africa Pre-Global Financial Crisis Years (1990-2006) 

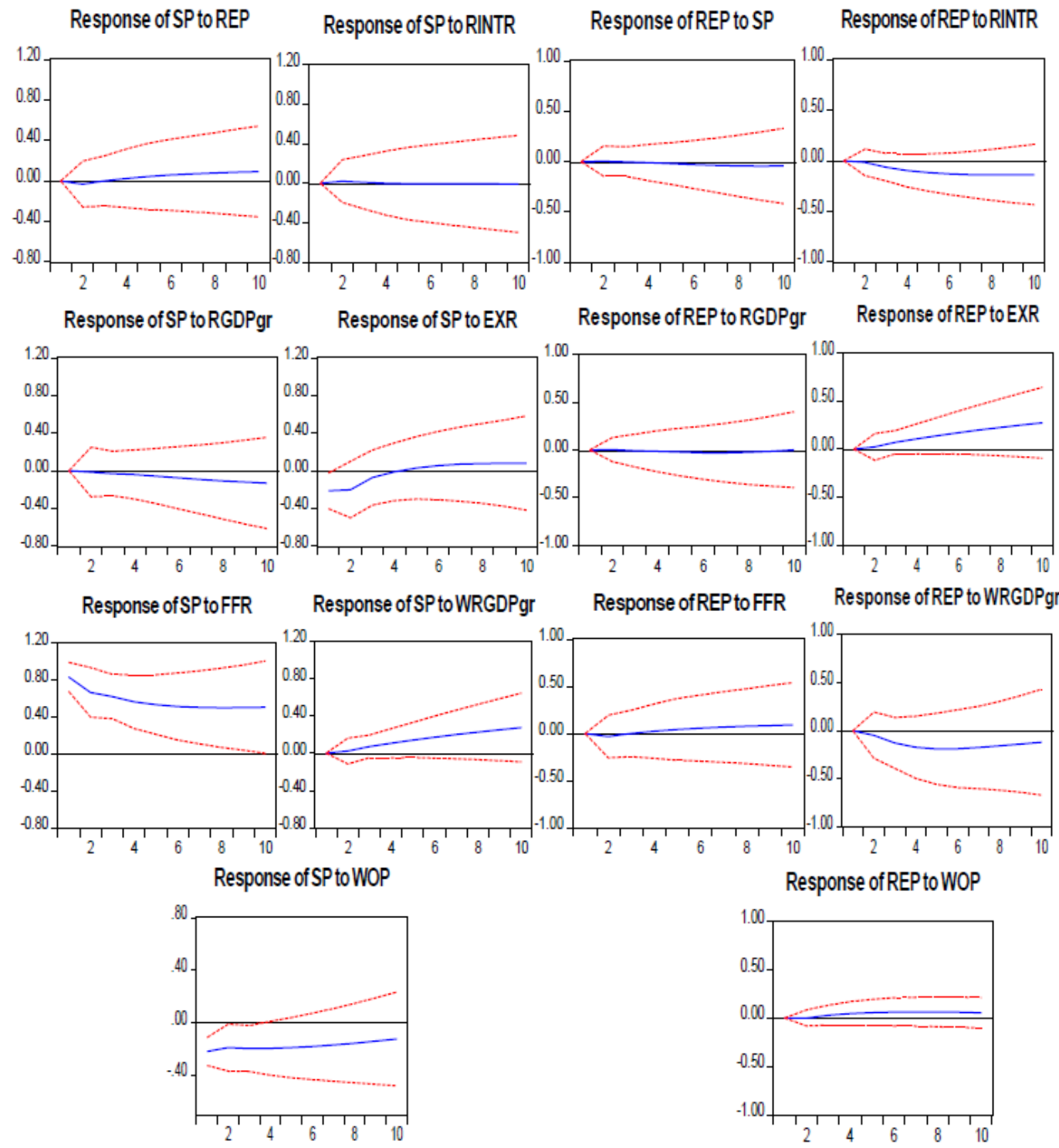

Figure 3b. Global Financial Crisis Years (2007-2016)

Figures $3 \mathrm{a}$ and $3 \mathrm{~b}$ depict impulse responses of both stock and real estate prices to a standard deviation shock from the macroeconomic variables in South Africa during expansion and crisis periods. Just like the results of the two countries earlier discussed in this study, a standard deviation shock from both stock and real estate prices still maintain positive and significant impacts on each other during the expansion period. The reverse is the case during the crisis period as the shocks from real estate prices have positive and insignificant impacts on stock price while the shocks from stock price inflict negative and insignificant impacts on real estate prices. Also, a standard deviation shock from RINTR, EXR, FFR, and WOP has negative impacts on the stock price during the expansion period. However, the case is now different during the crisis period as the shocks from RINTR, EXR, FFR, and WOP now have positive impacts on stock price; though, the positive impacts of the shocks from FFR and WOP are now more significant on stock price during the crisis period. 


\section{Al Macrothink}

Business and Economic Research

ISSN 2162-4860

2021, Vol. 11, No. 2

A standard deviation shock from RGDPgr and WRGDPgr has positive but insignificant impacts on stock price during the expansion period. A little difference is recorded during the crisis period as the shocks from RGDPgr now have negative but insignificant impacts on stock price, while the shocks from WRGDPgr still maintain positive but significant impacts on stock price during the crisis period. The responses of real estate prices to the shocks from RINTR, RGDPgr, FFR, WRGDPgr, and WOP are negative during the expansion period. Also, during the crisis period, the shocks from RINTR, RGDPgr, and WRGDPgr exert the same negative impacts on the real estate price except for FFR and WOP that now impact positively on real estate price. In addition, the shocks from EXR have negative impacts on real estate prices both in the expansion and crisis periods, but this positive impact is more significant during the crisis period.

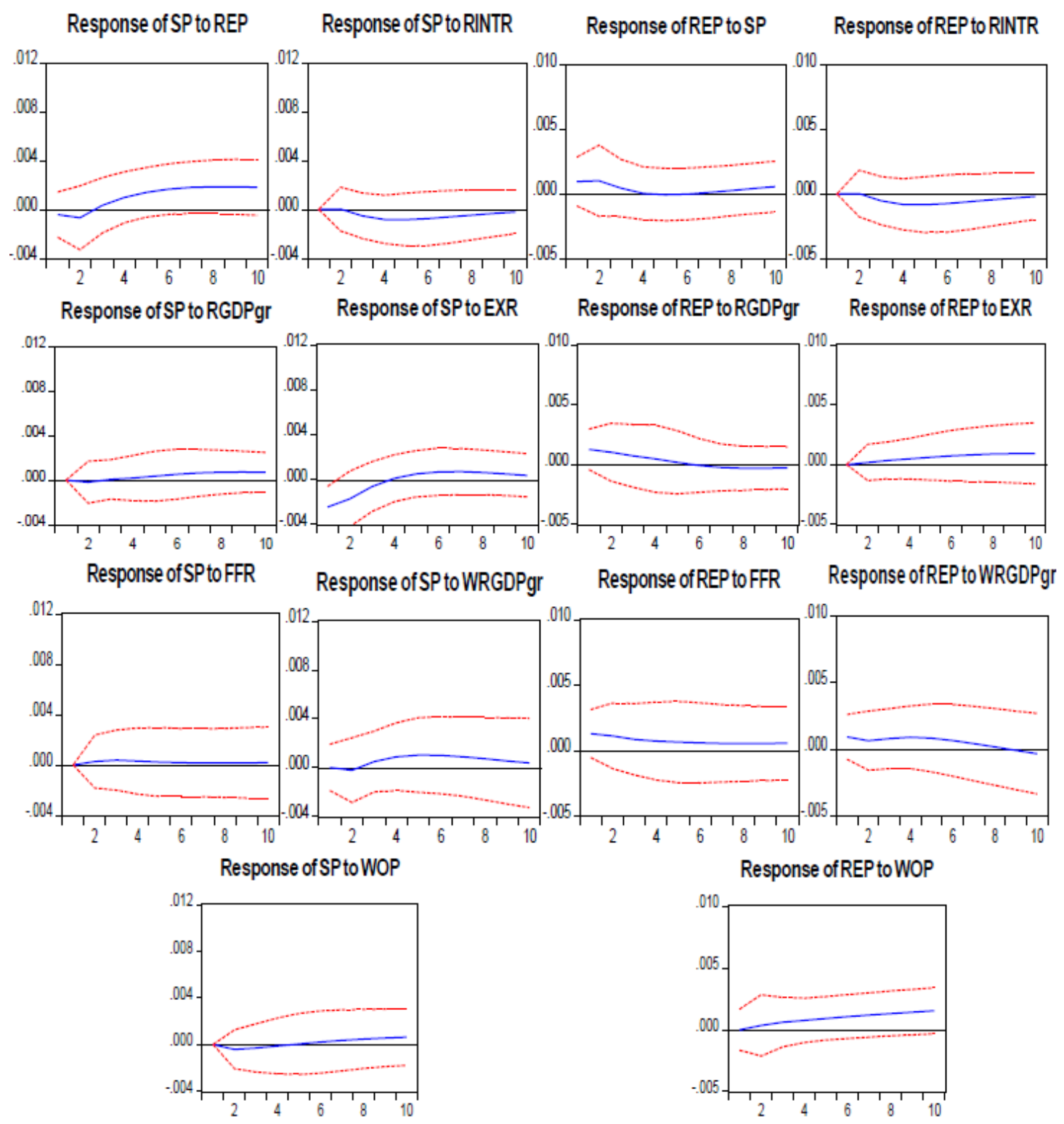

Figure 4a. Regime Dependent Impulse Response Functions for Kenya Pre-Global Financial Crisis Years (1990-2006) 

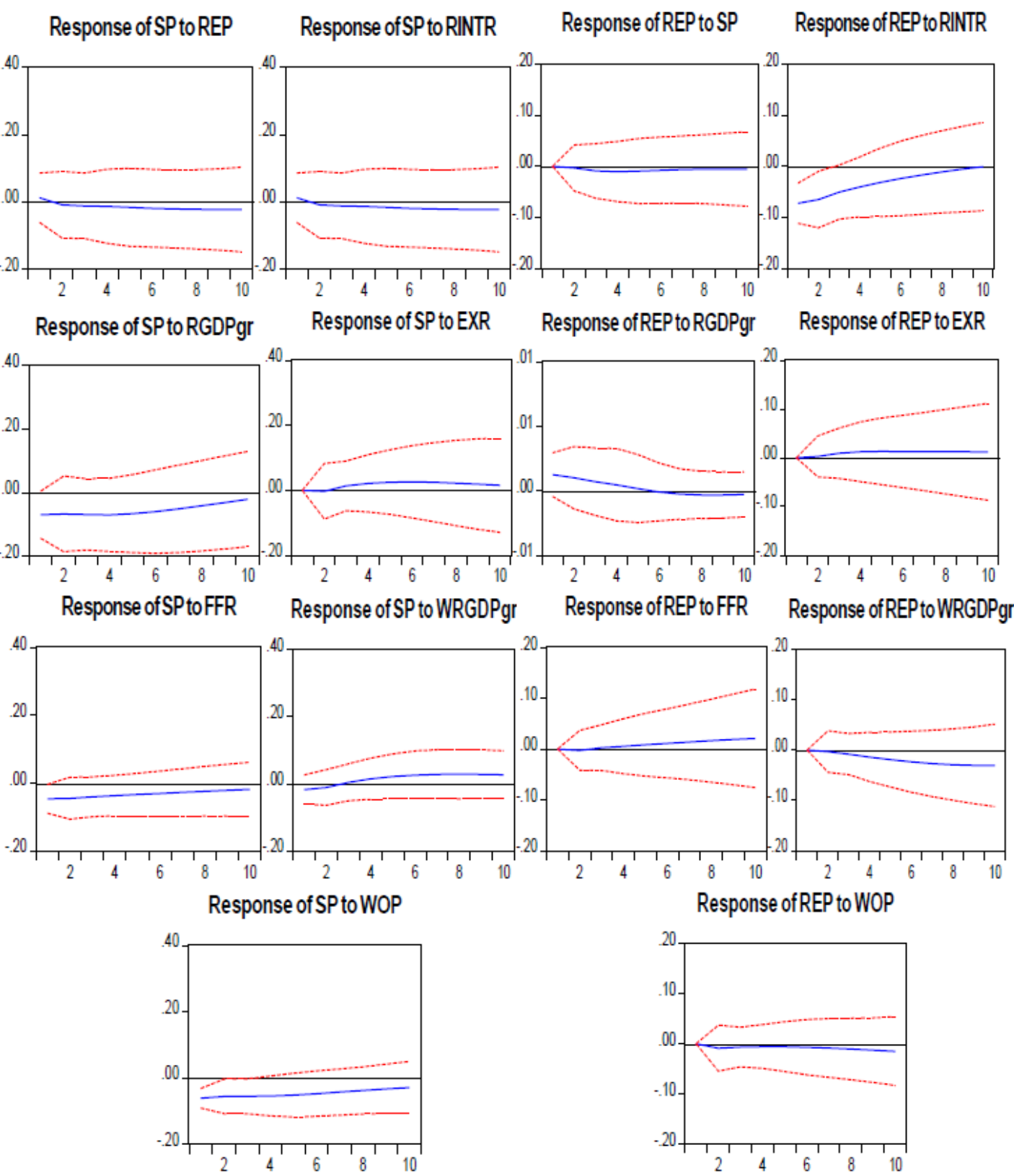

Figure 4b. Global Financial Crisis Years (2007-2016)

The regime dependent impulse response functions results in figures $4 a$ and $4 b$ show the responses of stock price and real estate prices to a standard deviation shock from macroeconomic variables in Kenya during the expansion and crisis periods. A standard deviation shock from both stock and real estate prices show the same positive impacts on each other during the expansion period. However, the case is quite different during the crisis period as the response of real estate prices to the shock from stock price is now negative while the response of stock price to the shock from real estate price is still positive. The shocks from RGDPgr, EXR, FFR, WRGDPgr, and WOP have positive impacts on stock price during the expansion period. But on the contrary, the shocks from RGDPgr, FFR, and WOP 
now inflict negative impacts on stock price while the shocks from EXR and WRGDPgr still maintain the same positive impacts on the stock price. A standard deviation shock from RINTR has a negative impact on stock prices during both expansion and crisis periods.

In addition, the responses of real estate prices to the shocks from RGDPgr, EXR, FFR, WRGDPgr, and WOP are positive during the expansion period. But the situation is now different during the crisis period as shocks from RGDPgr, WRGDPgr and WOP now have negative impacts on real estate prices, while the shocks from EXR and FFR still maintain the positive impacts on real estate price during the crisis period. Also, the responses of real estate prices to the shocks from RINTR are positive during both expansion and crisis periods in Kenya.

\subsection{Discussion of Findings}

The two panel cointegration tests conducted in "PANEL A" (i.e with and without cross-sectional dependence) show that there is no long-run relationship between the Stock Price and macroeconomic variables in the selected African countries. The reason for the lack of long-run relationships in this study might be attributed to the impact of behavioral finance on the relationship between macroeconomic factors and the Stock market which is prominent in most of the emerging markets particularly in Africa. Behavioral finance postulates that emotional biases through investor's irrationality create distortions and anomalies in the Stock market prices and returns, which may lead to a lack of long-term co-movements between macroeconomic factors and Stock Prices (Akintoye, 2008). The finding of no long-run relationship in this study is consistent with the works of Chiang, Nelling, and Tan (2008) and Frimpong (2012) who believe that the influence of rumors, sentiment, and extreme exuberance of investors can lead to a lack of long-term relationship between macroeconomic fundamentals and Stock Price in an emerging market. The long-run relationship segment in the Error-Correction Based Cointegration results in "PANEL A" further uphold the credibility of no long-run relationship as all the macroeconomic variables do not have a significant long-run relationship with the Stock Prices in the selected African countries

Similar to the findings obtained in "PANEL A", The two panel cointegration tests conducted in "PANEL B" (i.e with and without cross-sectional dependence) equally show a strong indication of no long-run relationship between the Real Estate price and macroeconomic variables in the selected African countries. This might be hinged on the nature of the Real Estate market in the emerging economies like Africa as the market is not fully efficient and therefore, does not incorporate all given information. This finding corroborates the assertions of Flannery and Protopapadakis (2002) who confirmed that a possible reason for a lack of long-run relationship between macroeconomic variables and Real Estate market Price in Africa might be due to the inability of the Real Estate market price to fully capture all information relevant to the change in the underlying macroeconomic fundamentals.

The SVAR Impulse Response Function results in this study reveal that a standard deviation shock from both Stock and Real Estate Prices have positive and significant impacts on each other during the expansion period in most of the African countries examined in this research work. The implication of this finding is that there is evidence of portfolio diversification 
benefits for both Stock and Real Estate markets in Africa during the boom period. In addition, this finding equally indicates significant evidence of wealth and credit-price effects in African Stock and Real Estate markets during the boom period. Wealth effect theory suggests that an increase in the Stock market prices brings about a need to re-balance investment portfolios by purchasing more Real Estate (Kapopoulos and Siokis, 2005). The credit-price effect theory also suggests that when Real Estate price increases, it raises the collateral value of Real Estate for firms to be able to borrow at a lower cost, thereby stimulating more investment in the stock market (Case and Shiller, 2005).

The results of SVAR Impulse Response Functions also show a positive and significant response of Stock and Real Estate Prices to the shock from Real GDP growth Rate (RGDPgr) during the expansion period which is prominent in most of the African countries examined. The positive relationships found in most of the African countries during the boom period indicate a healthy economic situation, thereby exerting a positive effect on the Stock and Real Estate market prices. On the other hands, the negative relationship between the two asset prices and Real GDP growth rate (RGDPgr) that is recorded during the recession period in most of the African countries in this study is a symbol of a bad economic situation that has an inverse effect on the assets' returns, thereby reducing their prices.

In another dimension, the results of SVAR Impulse Response Functions in this study reveal that a standard deviation shock from US Federal Fund Rate (FFR) exerts a highly significant impact on both Stock and Real Estate Prices during the Recession period in all the selected African countries in this research work. In other words, this finding can be better interpreted as a high sensitivity of African Asset markets to the U.S monetary policy shock during the crisis period. Obviously, this finding might not be unconnected with the countercyclical response of the U.S Federal Reserve Bank to the global financial crisis in 2007. In a bid to dampen the distress of the global financial crisis that started in 2007, U.S Federal Reserve Bank announced an unconventional monetary policy called "quantitative easing" in which it purchased a large number of government securities and other private sector assets in order to lower long-term interest rates.

This policy that was undertaken by U.S Federal Reserve actually crowded out private investment from the market thereby making the private investors shift their portfolio and move to close substitute assets in emerging markets particularly in Africa. This, therefore, contributed to the movement of investment funds (Capital inflows) from the U.S into the African asset market (Joyce, Miles, and Vayanos 2012). The sudden inflows of capital called "hot money" like the one caused by the U.S unconventional monetary policy is quite dangerous and unhealthy for African Asset markets. The short-term inflows of capital caused by U.S quantitative easing lead to an appreciation of the exchange rate which in turn causes a lack of competitiveness of most African exports. No wonder the negative impacts of FFR shocks on the Asset Prices of African countries like Nigeria (Stock and Real Estate prices), South Africa (Stock and Real Estate prices), and Kenya (Stock price) (as shown by the results of IRFs) corroborate the assertions of Mthuli and Daniel (2013) that the effect of US monetary policy shocks will be negative on countries with weak fundamentals during the economic crisis period. However, the positive impacts of FFR shock on the Asset Prices of 


\section{$\triangle$ Macrothink}

Egypt (Stock and Real Estate prices) and Kenya (Real Estate price) (as indicated by the results of IRFs) is in agreement with the position of Jiaqian, Tommaso, and Ratna (2014) that U.S unconventional monetary policy impacted positively on the emerging countries that have stronger fundamentals that could insulate against the shocks.

Finally, the results of SVAR Impulse Response Functions in this study show another finding that the responses of both Stock and Real Estate Prices to the World Oil Price (WOP) are highly significant during the crisis period in all the selected African countries in this research work. The results further revealed that shocks from WOP inflict negative impacts on the Stock and Real Estate Prices of the two major oil-producing African countries (Nigeria and Egypt) during the crisis period. This finding might no doubt be linked to a fall in the global oil price as a result of the global financial crisis that started in 2007. The report is consistent with the submission of Bjornland (2009) that an oil price decrease is expected to have a negative effect on the Asset prices of an oil-producing country. Also, the falling global oil price can be attributed to the positive impacts of WOP shocks on the net oil-importing African countries (South-Africa and Kenya) during the crisis period. This finding is in agreement with the assertions of LeBlanc and Chinno (2004) that reduction in oil price will have a positive impact on the Asset Prices of oil-importing countries.

\section{Conclusion}

Given the aforementioned results and findings in this study, the conclusion is therefore as follows:

First, there is no long-run relationship between the selected macroeconomic variables and Asset Prices (Stock and Real Estate Prices) during the period under review. Second, there is a more benefit of portfolio diversification of both the Stock and Real Estate market in Africa during the expansion period than in the crisis period. Third, the Real GDP growth rate (RGDPgr) of each country is a good determinant of both the Stock and Real Estate prices during expansion and recession periods. Fourth, the US Federal Fund Rate (FFR) is a better predictor of both Stock and Real Estate Prices during the crisis period than in the expansion period in Africa. Fifth, World Oil Price (WOP) is a better indicator of Stock and Real Estate Prices during the recession period than in the expansion period in Africa. Lastly, the relationship between macroeconomic shocks and asset prices (Stock and Real Estate Prices) is asymmetric in Africa over the two business cycle regimes (expansion and crisis period) explored in this research work.

\section{Reference}

Adam, A. M., \& Tweneboah, G. (2008). Do Macroeconomic Variables play any role in the Stock Market Movement in Ghana? European Journal of Economics, Finance and Administrative Sciences, 16(2), 128-140. https://doi.org/10.2139/ssrn.1152970

Akintoye, I. (2008). Efficient Market Hypothesis and Behavioural Finance: A review of Literature. European Journal of Social Sciences, 7(2), 7-17.

Asaolu, T. O., \& Ogunmuyiwa, M. S. (2011). An Econometric Analysis of the Impact of 
Macroeconomic Variables on Stock Market in Nigeria. Asian Journal of Business Management, 3(1), 72-78.

Azeez, A. A., \& Yonoezawa, Y. (2003). Macroeconomic Factors and the Empirical Content of the Arbitrage Pricing Theory in the Japanese Stock Market. International Journal of Economics and Finance, 45(3), 126-140.

Bekaert, G., \& Harvey, C. (1995). Time-varying World Market Integration. Journal of Finance, 50(2), 403-444. https://doi.org/10.1111/j.1540-6261.1995.tb04790.x

Bilson, C., Brailsford, T., \& Hooper, J. (2004). Selecting Macroeconomic Variables as Explanatory Factors of Emerging Stock Market Returns. Department of Commerce, Australian National University. Working Paper series in Finance, 23(2), 1-31.

Bjornland, H. C. (2009). Oil Price Shocks and Stock Market booms in an oil exporting country. Scottish Journal of political Economy, 2(5), 232-254.

https://doi.org/10.1111/j.1467-9485.2009.00482.x

Bjornland, H. C., \& Lietemo, K. (2009) Identifying the interdependence between US monetary policy and the stock market. Journal of Monetary Economics, 56, 275-282. https://doi.org/10.1016/j.jmoneco.2008.12.001

Buckberg, E. (1995). Emerging Stock Markets and International Asset Pricing. World Bank Economic Review, 9(1), 51-74. https://doi.org/10.1093/wber/9.1.51

Carter, M., \& Barrett, C. (2006). The Economics of Poverty Traps and Persistent Poverty: an Asset-Based Approach. Journal of Development Studies, 42(2), 178-199. https://doi.org/10.1080/00220380500405261

Case, K., \& Shiller, R. (2005). Comparing Wealth Effects: The Stock Market Versus the Housing Market. Journal of Macroeconomics, 5(1), 1-32.

https://doi.org/10.2202/1534-6013.1235

Central Intelligence Agency. (2008). The World Fact Book. pp. 234-254.

Chaudhuri, K., \& Smiles, S. (2004). Stock Market and Aggregate Economic Activity: Evidence from Australia. Applied Financial Economics, 14(2), 121-129. https://doi.org/10.1080/0960310042000176399

Chiang, T., Nelling, E., \& Tan, L. (2008). The Speed of Adjustment to Information: Evidence from the Chinese Stock market. International Review of Economics and Finance, 17(2), 216-229. https://doi.org/10.1016/j.iref.2007.06.004

Elbourne, A. (2008). The UK Housing Market and the Monetary Policy Transmission Mechanism: An SVAR Approach. Journal of Housing Economics, 88(2), 65-87. https://doi.org/10.1016/j.jhe.2007.09.002

Elton, E. J., Gruber, M. J., \& Brown, S. J. (2003). Modern Portfolio Theory and Investment Analysis. Journal of Finance, 76(3), 67-93. 
Flannery, M., \& Protopapadakis, A. (2002). Macroeconomic Factors do Influence Aggregate Stock Returns. Review of Financial Studies, 15(2), 751-782.

https://doi.org/10.1093/rfs/15.3.751

Frimpong, J. (2009). Economic Forces and the Stock Market in a developing Economy: Cointegration Evidence from Ghana. European Journal of Economics, Finance and Administrative Sciences, 16(2), 128-140.

Frimpong, J. (2012). Speed of Adjustment of Stock Prices to Macroeconomic Information: Evidence from Ghanaian Stock Exchange (GSE). International Business and Management, 2(1), 1-6.

Gan, C., Lee, M., Yong, H., \& Zhang, J. (2006). Macroeconomic variables and Stock Market Interactions: New Zealand Evidence. Investment Management and Financial Innovation, 3(4), 89-101.

Garcia, R., \& Schaller, H. (2002). Are the Monetary Output Effects Asymmetric?. Economic Inquiry, 40(3), 102-119. https://doi.org/10.1093/ei/40.1.102

Gottschalk, J. (2001). An Introduction into the SVAR Methodology. Identification, Interpretation and Limitations of SVAR models. Kiel working paper, No. 1072.

Gupta, R., \& Kabundi, K. (2010). The Effect of Monetary Policy on Real House Price Growth in South Africa. A Factor Augmented Vector Autoregression (FAVAR) Approach, Economic Modeling. https://doi.org/10.1016/j.econmod.2009.09.011

Harvey, C. (1995). The Risk Exposure of Emerging Equity Markets. World Bank Economic Review, 9(1), 19-50. https://doi.org/10.1093/wber/9.1.19

IMF World Economic Outlook. (2003). Compilation Guide on Financial Soundness Indicators. Washington D.C. https://doi.org/10.5089/9781498329712.007

International Monetary Fund. (2008). De Facto Classification of Exchange Rate Regimes and Monetary policy Framework. [Online] Available:

http://www.imf.org/external/np/mfd/er/2008/1205/htm

Iscan, B., \& Xu, K. (2010). The Impact of Monetary Policy Shocks on Stock Prices: Evidence from Canada and United State. Journal of International Money and Finance, 29(5), 876-896. https://doi.org/10.1016/j.jimonfin.2010.03.008

Jiaqian, C., Tommaso, M., \& Ratna, S. (2014). Spillover from United States Monetary Policy on Emerging Markets: International Monetary Fund Working Paper Series. WP/14/240.

Joyce, M., Miles, D., \& Vayanos, D. (2012). Quantitative Easing and Unconventional Monetary Policy. Economic Journal, 122(564), 271-288.

https://doi.org/10.1111/j.1468-0297.2012.02551.x

Jose, B. M., \& Massa, I. (2009). The Global Financial Crisis and Sub Saharan Africa, The Effects of Slowing Private Capital Inflows on Growth. Working Paper 304, Overseas Development Institute, London. 
Kapopoulos, P., \& Siokis, F. (2005). Stock and Real Estate Prices in Greece: Wealth versus Credit-Price Effect. Applied Economic Journal, 12(2), 125-128.

https://doi.org/10.1080/1350485042000307107

Kyereboah, C., Anthony, A. T., \& Kwame, F. (2008). Impact of Microeconomic Indicators on Stock Exchange Performance: The Case of the Ghana Stock Exchange. Journal of Risk Finance, 35(2), 27-41.

LeBlanc, M., \& Chinno, D. (2004). Do High Oil Prices cause Inflation? The evidence from G5 countries. Business Economics, 34(2), 38-48. https://doi.org/10.2139/ssrn.509262

Mak, S., \& Choy, L. (2012). Region-Specific Estimates of the Determinants of Real Estate Investments in China. Urban Studies, 49(4) 741-755.

https://doi.org/10.1177/0042098011407093

Malpezzi, S. (1999). A Simple Error Correction Model of House Prices. Journal of Housing Economics, 8(3), 27-62. https://doi.org/10.1006/jhec.1999.0240

Mthuli, N., \& Daniel, Z. (2013). Global Economic Spillovers to Africa: A GVAR Approach. African Development Bank Group Working Paper Series, 183(4), 1-31.

Muli, J. (2011). The Relationship between Property Prices and Mortgage Lending in Kenya. Unpublished MBA Project, University of Nairobi.

Muthike, S. W., \& Sakwa, M. M. (2011). Can Macroeconomic Indicators be used as predictors of the Stock Exchange Index Trends?. A Look at the Nairobi Stock Exchange, Jomo Kenyatta University of Agriculture and Technology, Nairobi.

Narayan, S., \& Narayan, P. (2012). Do US macroeconomic conditions affect Asian stock markets?. Journal of Asian Economics, 23(6), 669-679.

https://doi.org/10.1016/j.asieco.2012.05.001

Nile Capital Management. (2012). Nile Pan Africa Fund (Nafax). [Online] Available: http://www.nilefunds.com

Ochieng, D. E., \& Oriwo, E. A. (2012). The Relationship between Macroeconomic variables and Stock Market Performance in Kenya. DBA African Economic Review, 3(2), 38-49.

Ojetunde, I., Popoola, N. I., \& Kemiki, O. A. (2011). The Interaction between the Nigerian Residential Property Market and the Macroeconomy. Journal of Geography, Environment and Planning, University of Ado-Ekiti, Nigeria, 7(2), 56-70.

Olalere, D. O. (2006). An Empirical Investigation into the Determinants of Stock Market behavior in South Africa. Unpublished Master Theses. Grahams town, Rhodes University.

Olukayode, F., \& Akinwande, M. (2009). Long and Short-run Shocks from Macroeconomic variables on the Nigerian Capital Market. Journal of Economics and International Finance, $3(2), 605-615$.

Osamuonyi, I. O., \& Evbayiro-Osagie, I. (2012). The Relationship between Macroeconomic 


\section{Macrothink}

Business and Economic Research ISSN 2162-4860 2021, Vol. 11, No. 2

Variables and Stock Market Index in Nigeria. Journal of Economics, 3(2), 55-63. https://doi.org/10.1080/09765239.2012.11884953

Orman, M. (2003). Time Series Analysis of the Impact of Real Interest Rates on Stock Market Activity and Liquidity in Egypt. Cointegration and Error Correction Model Approach. International Journal of Business, 121(7), 100-121. https://doi.org/10.2139/ssrn.420248

Persyn, D., \& Westerlund, J. (2008). Error Correction Based Cointegration Tests for Panel Data. The stata Journal, 8(2), 232-241. https://doi.org/10.1177/1536867X0800800205

Pesaran, M. H. (2013). Testing Weak Cross-sectional Dependence in large Panels. Forthcoming in Econometric Reviews, 45(3), 34-54.

Peter, H., \& Frank, P. (2006). Understanding Asset Prices, an Overview. Autumn Meeting of Central Bank Economists. BIS Papers No 34.

Pirovano, M. (2012). Monetary Policy and Stock prices in Small Open Economies. Empirical Evidence for the New EU Members States. Economic Systems, 36(5), 372-390.

https://doi.org/10.1016/j.ecosys.2012.06.001

Raghvan, M., Silvapulle, P., \& Athanasopoulos, G. (2012). Structural VAR model for Malaysian Monetary Policy analysis during the Pre and Post 1997 Asian Crisis Periods. Applied Economics, 44(29), 3841-3856. https://doi.org/10.1080/00036846.2011.581360

Rothacher, N. (2015). Maturity of Real Estate Markets in Sub-Saharan Africa: A comparison between Tanzania and South Africa. International Real Estate Business School, IRE/BS, University of Regensburg, Germany.

Roll, R., \& Ross, S. A. (1986). Economic Forces and the Stock Market. The Journal of Business, 59(3), 383-403. https://doi.org/10.1086/296344

Ross, S. A. (1976). The Arbitrage Pricing Theory of Capital Asset pricing. Journal of Economic Theory, 13(4), 341-360. https://doi.org/10.1016/0022-0531(76)90046-6

Sims, C. A. (1980). Macroeconomics and reality. Econometrica, 48(1), 1-48. https://doi.org/10.2307/1912017

Tsatsoronis, K., \& Zhu, H. (2004). What Drives Housing price Dynamics: Cross-Country Evidence?. BIS Quarterly Review, 54(3), 37-57.

Westerlund, J. (2007). Testing for Error Correction in Panel Data. Oxford Bulletin of Economics and Statistics, 69(6), 709-748. https://doi.org/10.1111/j.1468-0084.2007.00477.x

World Bank. (2009). Global Monitoring Report. A Development Emergency Washington D.C

\section{Copyright Disclaimer}

Copyright for this article is retained by the author(s), with first publication rights granted to the journal.

This is an open-access article distributed under the terms and conditions of the Creative Commons Attribution license (http://creativecommons.org/licenses/by/4.0/). 